\title{
CEsifo \\ WORKING

\section{How to Deal with the Risks of Phasing out Coal in Germany through National Carbon Pricing}

Sebastian Osorio, Robert C. Pietzcker, Michael Pahle, Ottmar Edenhofer 


\section{Impressum:}

CESifo Working Papers

ISSN 2364-1428 (electronic version)

Publisher and distributor: Munich Society for the Promotion of Economic Research - CESifo $\mathrm{GmbH}$

The international platform of Ludwigs-Maximilians University's Center for Economic Studies and the ifo Institute

Poschingerstr. 5, 81679 Munich, Germany

Telephone +49 (o)89 2180-2740, Telefax +49 (o)89 2180-17845, email office@cesifo.de

Editors: Clemens Fuest, Oliver Falck, Jasmin Gröschl

www.cesifo-group.org/wp

An electronic version of the paper may be downloaded

- from the SSRN website: $\quad$ www.SSRN.com

- from the RePEc website: $\quad$ www.RePEc.org

- from the CESifo website: www.CESifo-group.org/wp 


\title{
How to Deal with the Risks of Phasing out Coal in Germany through National Carbon Pricing
}

\begin{abstract}
Germany aims to phase out coal to achieve its 2030 climate target, for which a UK-style carbon price floor is considered. But this measure comes with risks related to the uncertainty about what price level is sufficient, and the waterbed effect arising from unilateral policy under the EU-ETS. Quantifying these risks we find that to be on the "safe side" target-wise, the price must be nearly twice as high as the reference scenario price $\left(33 € / \mathrm{tCO}_{2}\right)$. Further, cancelling 1.1 $\mathrm{GtCO}_{2}$ of certificates and forming coalitions with other countries is essential to reduce the risk that EU climate policy will renationalize.
\end{abstract}

JEL-Codes: L940, Q580.

Keywords: EU-ETS, carbon price floor, coal phase-out, policy interaction, waterbed effect.

Sebastian Osorio*

Potsdam Institute for Climate Impact Research

Potsdam / Germany

sebastian.osorio@pik-potsdam.de

Michael Pahle

Potsdam Institute for Climate Impact Research

Potsdam / Germany

michael.pahle@pik-potsdam.de
Robert C. Pietzcker

Potsdam Institute for Climate Impact Research

Potsdam / Germany

pietzcker@pik-potsdam.de

Ottmar Edenhofer

Potsdam Institute for Climate Impact Research \& Mercator Research Institute on Global Commons and Climate Change, Berlin \& TU

Berlin / Germany

ottmar.edenhofer@pik-potsdam.de

*corresponding author 


\section{INTRODUCTION}

If Germany is to achieve its mid-term (2030) and long-term (2050) climate targets, power production from coal in the country must be substantially reduced and eventually completely phased out. In 2010, the German government formulated the target to reduce greenhouse gas (GHG) emissions by $40 \%$ by $2020,55 \%$ by $2030,70 \%$ by 2040 , and $80-95 \%$ by 2050 relative to 1990 levels (BMWi and BMU, 2010). Yet, in the course of the decade it became clear that the 2020 target - as well as subsequent targets - will not be met. As a consequence, the German government devised an action plan to reach the 2050 and intermediate targets (BMUB, 2016). This plan includes sector-specific targets for 2030 and proposed measures for achieving them. The energy conversion sector plays a particularly important role: in 2016 it accounted for $37 \%$ (332 Mt) of all GHG emissions in the country. Within this sector, the lion's share of emissions came from coal power generation. In 2016 lignite and hard coalfired power plants emitted $249.1 \mathrm{MtCO}_{2}$, equalling $81 \%$ of the total $\mathrm{CO}_{2}$ emissions of the German electricity sector: 51\% from lignite and 30\% from hard coal (BMWi, 2018). Moreover, some of Germany's coal plants $(\sim 11 \mathrm{GW})$ were only built in the last decade to replace the nuclear plants that will be phased out in the coming years (Pahle, 2010). In the face of that, the government set up a commission in June 2018 to propose measures to achieve the 2030 target and an "end date" for the use of coal (Die Bundesregierung, 2018).

One of the measures discussed is a national $\mathrm{CO}_{2}$ price floor, which would be realized by a national support price on top of the ETS allowance price, as called for by, for example, Agora and IDDRI (2017), Edenhofer and Schmidt (2018), and Matthes et al. (2018). Such a policy was implemented in the UK in 2013. Thus far it has proved to be successful in displacing coal generation in favour of more gas generation (Staffell, 2017). The obvious advantages of this measure are: (a) that it can be unilaterally implemented ${ }^{1}$ to set a carbon price that - regardless of the future ETS price - is high enough to reach Germany's national target; and (b) that it is more efficient than phasing out coal through a command-and-control approach. It also comes with two important risks: First, unilateral action in general leads to a waterbed effect in the EU's Emission Trading Scheme (ETS). This form of leakages has been described by the Netherlands Environmental Assessment Agency (2008), Goulder and Stavins (2011), and Edenhofer et al. (2017). Importantly, it undermines the integrity of the EU ETS. If strong enough, over time it may lead to a downward spiral that can put the existence of the EU ETS at risk (Pahle et al., 2018). A second risk relates to the uncertainty of achieving the national

\footnotetext{
${ }^{1}$ See Hermann et al. (2017) for a legal assessment.
} 
climate target. If mitigation costs are uncertain, $\mathrm{a} \mathrm{CO}_{2}$ price can achieve a quantity target also only with uncertainty (cf. Weitzman 1974). In particular effects are very sensitive to fuel prices, interest rates, and capital costs (Newbery 2018). In other words, with carbon pricing an overshoot or undershoot of the target is most likely and thus creates a respective risk.

We quantify these risks using the numerical power market model LIMES-EU and consider different options for dealing with them. We first assess which national $\mathrm{CO}_{2}$ price level is needed in a baseline scenario to achieve the German 2030 climate target for electricity generation. We then conduct a comprehensive sensitivity analysis to determine the range of this price under different assumptions for uncertain policy and economic parameters. Subsequently, we turn to the risks for the EU ETS related to the waterbed effect. We consider two options for addressing this effect: (a) multilateral cooperation with other ambitious countries like France and the Netherlands that are also willing to implement such an instrument on a national or even regional basis (Carbon Market Watch, 2017; Reuters, 2018); and (b) cancellation of allowances in line with the provisions introduced in the recent reform of the EU ETS ${ }^{2,3}$ (Market Stability Reserve (MSR), national level). The first option has potential to reduce the waterbed effect, but is also attractive as a policy sequence (Pahle et al., 2018) that could lead to an EU-wide approach to climate policy in the future. Edenhofer and Schmidt (2018) and Matthes (2017) describe such a sequence. Our working hypothesis is that a well-designed coal phase-out in Germany does not undermine the EU ETS in the mid-term, and could even enable an EU-wide approach after 2030. The facilitation of an EU-wide approach seems essential in the long-run, and any national action that would not lead up to it would be in vain. We will come back to this in the conclusions.

\footnotetext{
${ }^{2}$ The EU's parliament and council in 2017 eventually agreed to reform the ETS, which will take effect in the $4^{\text {th }}$ phase (from 2021 to 2030) (European Council, 2017a). These reforms are comprised of an increase of the linear reduction factor (2.2\% annually compared to the $1.74 \%$ in the $3^{\text {rd }}$ phase) setting the annual cap and a revision of the previously agreed upon Market Stability Reserve (MSR) (European Union, 2015) with the aim of reducing the current market surplus of around $1.6 \mathrm{GtCO}_{2}$ of allowances (EEA, 2017a). The MSR was originally created with an amendment of the Directive 2003/87/EC (EC, 2015) and will start operating in 2019: 900 million 'backloaded allowances' will be placed on the MSR (instead of being auctioned in 2019-2020) and the unallocated allowances will be transferred to the MSR in 2020 (European Council, 2017b). The recent revision establishes banking thresholds to determine the amount of certificates that will be withheld from (intake of the MSR) or backloaded to (outtake of the MSR) the market. From 2023 on, the number of allowances in the MSR exceeding the number of allowances auctioned the previous year will be cancelled. This provision could compensate the effects of uncoordinated national measures and thus avoid the waterbed effect, at least partially (Burtraw et al., 2018; Graichen and Matthes, 2018; Perino, 2018). For details of the reform, see: http://www.consilium.europa.eu/en/press/press-releases/2017/11/22/reform-of-the-eu-emissions-trading-systemcouncil-endorses-deal-with-european-parliament/.

3 The new ETS Directive 2018/410 entails that "Member States should have the possibility of cancelling allowances from their auction volume in the event of closures of electricity-generation capacity in their territory"; see http://eur-lex.europa.eu/legal-content/EN/TXT/PDF/?uri=CELEX:32018L0410\&from=EN
} 
Our work relates to two strands of literature: First, the strand that addresses overlapping policies and policy interaction between the EU ETS and national policies. See Fischer and Preonas (2010) for theoretical considerations and a review of the early literature. Numerical work in the last years has focussed mainly on renewable policies, e.g. Weigt et al. (2013) and Van den Bergh et al. (2013). Second, literature covering scenario analyses of the German coal phase-out. Nearly all of this work, which we review in more detail in the following section, is grey literature and has been conducted specifically in the context of the German policy debate. This literature deals with policy interactions with the EU ETS very superficially, for instance by assuming ETS prices to be exogenous. Both literature strands put very little emphasis on the risks that come with policy design and interactions.

Our study goes beyond the existing literature in the following ways: (1) We analyse the German coal phase-out specifically from a risk perspective, and examine ways of dealing with these risks, which is crucial for making the right policy choices. To assess the risk of over- or undershooting the national climate target, we conduct a comprehensive sensitivity analysis, which also considers the future role of the ETS industry sector - a step neglected in previous work. (2) We rigorously consider policy interaction with the EU ETS and the related risks that come with national approaches. We do this by separating the different components of the waterbed effect as alluded to by Begemann et al. (2016) and Sandbag (2017): the trade-related waterbed effect "in space" that arises from an immediate relocation of production to other markets; and the waterbed effect "in time", which results from lower demand for allowances and the corresponding banking of allowances for future use. The implications of the waterbed effect "in time" are particularly under-researched, which is why (in contrast to most other studies) we analyse the full ETS time horizon up to 2050. (3) We consider how cancellation of the MSR from 2023 could reduce the waterbed effect, as analysed by Perino (2018), Burtraw et al. (2018), and Pahle et al. (2018).

The paper is organised as follows. Section 2 summarizes the main studies and papers dealing with the coal phase-out in Germany. Section 3 describes the model, the main assumptions and the different scenarios. Section 4 discusses the results. Finally, in Section 5 we conclude and provide the main insights from our research.

\section{LITERATURE REVIEW}

The aforementioned work addressing the coal phase-out in Germany varies widely in terms of approach and sectors covered. Importantly, almost all of the recent studies are grey literature 
that deal with the economic questions of policy interaction relatively superficially. Table 1 summarizes the studies focused on determining an exogenous phase-out schedule based on different allocation rules. The most common rule is to limit the lifespan of lignite and hard coal plants, but there are also studies proposing more complex rules like a emission performance standard (EPS) (Matthes et al., 2017) or a certificate system based on plants efficiency to allocate production (Klaus et al., 2012). Klaus et al. (2012) only focus on developing a methodology to determine the decommissioning path without performing model-based analysis. All other studies analyse the effect of the proposed coal phase-out paths on the German market, and some at the EU-level, in terms of the evolution of other technologies (mainly gas and RES), of export/import surplus and of electricity prices. The time horizon of studies modelling the electricity market is at least 2030.

The completion dates for coal phase-out in most studies is later than 2040. In some scenarios, some coal power remains in 2050. In some cases, late phase-out prevents targets from being reached (Heinrichs et al., 2017). While current German targets focus on specific years (e.g., $40 \%$ reduction by 2020 in Germany) and include a date for the final phase-out of coal, some studies are based on long-term emission budgets, as cumulated $\mathrm{CO}_{2}$ emissions (not just the emissions in a certain target year) are relevant for the climate (Meinshausen et al., 2009). The SRU (2017) suggests that the total German $\mathrm{CO}_{2}$ budget from coal generation should not exceed $2 \mathrm{GtCO}_{2}$. Matthes et al. (2017) derives a budget of $4 \mathrm{GtCO} 2$ for the German electricity sector (implying a substantially smaller budget for coal generation emissions, due to residual gas generation emissions), which they use as a reference to analyse the impact of different coal phase-out paths. As the emissions from coal were high $\left(249 \mathrm{MtCO}_{2}\right)$ in 2015 , staying within these budgets requires a prompt reduction of coal emissions - if coal use was unabated, the total budget until 2050 would be exhausted in just eight years (SRU, 2017). An early reduction is also important for enhancing the credibility of climate policy and for limiting potential distortions due to incumbents' myopia (Knopf et al., 2018). 
Table 1.Selected studies and papers analysing the impact of a regulated coal phase-out in Germany.

\begin{tabular}{|c|c|c|c|c|c|c|c|}
\hline \multirow[t]{2}{*}{ Study } & \multirow{2}{*}{$\begin{array}{l}\text { Type } \\
\text { of } \\
\text { study } \\
\text { a }\end{array}$} & \multirow[t]{2}{*}{ Sector } & \multirow[t]{2}{*}{ Region } & \multirow{2}{*}{$\begin{array}{l}\text { Time } \\
\text { horizon }\end{array}$} & \multirow[t]{2}{*}{$\mathrm{CO}_{2}$ price } & \multicolumn{2}{|l|}{ Coal phase-out (CPO) } \\
\hline & & & & & & Scenario/Criteria & CPO completed when? \\
\hline \multirow[t]{2}{*}{$\begin{array}{l}\text { Agora } \\
\text { Energiewende } \\
(2016)\end{array}$} & \multirow[t]{2}{*}{ GL } & \multirow[t]{2}{*}{ Electricity } & \multirow[t]{2}{*}{$\begin{array}{l}\text { most countries } \\
\text { EU }\end{array}$} & \multirow[t]{2}{*}{$2015-2040$} & \multirow[t]{2}{*}{$\begin{array}{l}13 € / \mathrm{tCO}_{2} \text { in } 2020 \\
\text { to } 39 € / \mathrm{tCO}_{2} \text { in } \\
2040\end{array}$} & Ref: 40y Hard coal and 50y lignite lifespan & -- \\
\hline & & & & & & $\begin{array}{l}\text { Coal Consensus Path 2040: Remaining } \\
\text { plant lifespans }\end{array}$ & 2040 \\
\hline \multirow[t]{2}{*}{$\begin{array}{l}\text { Matthes et al. } \\
(2017)-\text { WWF }\end{array}$} & \multirow[t]{2}{*}{ GL } & \multirow[t]{2}{*}{ Electricity } & \multirow[t]{2}{*}{$\begin{array}{l}\text { most countries } \\
\text { EU }\end{array}$} & \multirow[t]{2}{*}{$2015-2050$} & \multirow[t]{2}{*}{$\begin{array}{l}10 € / \mathrm{tCO}_{2} \text { in } 2020 \\
\text { to } 60 € / \mathrm{COO}_{2} \text { in } \\
2050 \text { (exogenous) }\end{array}$} & $\begin{array}{l}\text { Transformation: } 30 \mathrm{y} \text { lifespan and EPS } \\
\text { between the } 21 \text { th and the } 30^{\text {th }} \text { year of } 3.35 \\
\mathrm{tCO}_{2} / \mathrm{Kwh}\end{array}$ & 2035 \\
\hline & & & & & & $\begin{array}{l}\text { Other } 7 \text { scenarios with lifespan of }<20 y- \\
30 y\end{array}$ & before 2050 in all the cases \\
\hline $\begin{array}{l}\text { Pietroni et al. } \\
(2017) \\
\text { Greenpeace }\end{array}$ & GL & Electricity & $\begin{array}{l}\text { most countries } \\
\text { EU }\end{array}$ & $2015-2030$ & $\begin{array}{l}\text { Increase from } 10 \text { to } \\
35 € / \mathrm{tCO}_{2} \text { in } 2030 \\
\text { (from } \mathrm{WEO}, 2016 \text { ) }\end{array}$ & $\begin{array}{l}\text { Ecologic merit-order (most inefficient } \\
\text { plants are decommissioned first) }\end{array}$ & 2030 \\
\hline \multirow{3}{*}{$\begin{array}{l}\text { Heinrichs et al. } \\
(2017)\end{array}$} & \multirow[t]{3}{*}{ PR } & \multirow[t]{3}{*}{ Energy } & \multirow[t]{3}{*}{ Germany } & \multirow[t]{3}{*}{$2015-2050$} & \multirow{3}{*}{$\begin{array}{l}15 \quad € 2015 / \mathrm{tCO}_{2} \\
(2020) \text { to } 37 \\
€ 2015 / \mathrm{tCO}_{2}(2050) \\
\text { (from } \mathrm{WEO}, 2014)\end{array}$} & 50y lignite and $45 \mathrm{y}$ hard coal & -- \\
\hline & & & & & & Path from (Klaus et al., 2012) & 2040 \\
\hline & & & & & & FPO: from survey & 2020 \\
\hline \multirow{2}{*}{$\begin{array}{l}\text { Heinrichs and } \\
\text { Markewitz (2017) }\end{array}$} & \multirow[t]{2}{*}{ PR } & \multirow[t]{2}{*}{ Energy } & \multirow[t]{2}{*}{ Germany } & \multirow[t]{2}{*}{$2015-2050$} & \multirow{2}{*}{$\begin{array}{l}15 \quad € 2000 / \mathrm{tCO}_{2} \\
(2020) \text { to } 30 \\
€ 2000 / \mathrm{tCO}_{2}(2050) \\
\text { (from } \mathrm{WEO}, 2015)\end{array}$} & 50y lignite and $45 \mathrm{y}$ hard coal & -- \\
\hline & & & & & & Path from (Klaus et al., 2012) & 2040 \\
\hline \multirow{3}{*}{$\begin{array}{ll}\text { Enervis } & \text { Energy } \\
\text { Advisors } & (2015)- \\
\text { Agora } & \end{array}$} & \multirow[t]{3}{*}{ GL } & \multirow[t]{3}{*}{ Electricity } & \multirow[t]{3}{*}{ EU } & \multirow[t]{3}{*}{$2015-2040$} & \multirow{3}{*}{$\begin{array}{l}13 € / \mathrm{tCO}_{2} \text { in } 2020 \\
\text { to } 39 € / \mathrm{tCO}_{2} \text { in } \\
2040 \text { (from WEO, } \\
2014 \text { ) }\end{array}$} & $\begin{array}{l}\text { Ref: } 40 \mathrm{y} \text { hard coal and } 50 \mathrm{y} \text { lignite lifespan } \\
+10 \mathrm{y} \text { retrofit possible if profitable }\end{array}$ & -- \\
\hline & & & & & & No-retrofit: As Ref, but with fixed lifespan & -- \\
\hline & & & & & & $\begin{array}{l}\text { Climate scenario: early decommissioning } \\
\text { based on the abatement costs, necessary to } \\
\text { reach the emission reduction path }\end{array}$ & -- \\
\hline $\begin{array}{l}\text { Klaus et al. (2012) } \\
\text { - Greenpeace }\end{array}$ & GL & -- & -- & -- & -- & $\begin{array}{l}\text { Coal-based generation capped, and } \\
\text { certificates allocated based on efficiency }\end{array}$ & 2040 \\
\hline
\end{tabular}

${ }^{a}$ GL: Grey literature; PR: Peer-reviewed paper 
Importantly, the waterbed effect gets limited attention in the aforementioned studies. Although Agora Energiewende (2016) warns about the need to reform the EU ETS to avoid the waterbed effect, it is not assessed. Enervis Energy Advisors (2015) calculates that a 50\% emission reduction in Germany would be offset by an increase in other EU countries, but it is unclear to which time horizon this corresponds.

The waterbed effect receives more attention in the studies that explore the effects of a $\mathrm{CO}_{2}$ price for Germany or a coalition of countries. Four studies were identified (see Table 2) in which at least Germany implements a higher $\mathrm{CO}_{2}$ price than the rest of the EU - all have a time horizon no longer than 2030. Only in one study (Matthes et al., 2018) is the impact of a coalition evaluated (countries of centre-western Europe (CWE)). These studies focus primarily on exploring different price levels in order to find the one(s) that allows the German target (emission reduction of $40 \%$ in 2020 and $61 \%$ in 2030) to be reached. There is little discussion about how these levels may be affected by uncertainties and where the risks lie. The intertemporal nature of the EU ETS is also omitted in the static nature of the approaches.

The effective $\mathrm{CO}_{2}$ prices in these studies lie between 15 and $80 € / \mathrm{tCO}_{2}$ in Germany and between 5 and $30 € / \mathrm{tCO}_{2}$ in the rest of $\mathrm{EU} .75 € / \mathrm{tCO}_{2}$ is the largest carbon price support applied in Germany. The wide range of $\mathrm{CO}_{2}$ prices highlights the uncertainty about the evolution of the EU ETS even in the medium term. The German power sector emissions that would result lie between 102 and $262 \mathrm{MtCO}_{2}$ by 2020 , which implies a reduction of $28-72 \%$ compared to 1990 levels. In Table 2, the waterbed effect in a specific year is measured as the ratio between the increase of non-German emissions (with respect to a reference scenario) and the reduction in German emissions (with respect to the same reference scenario, whose assumptions depend on each study). Values range between 24 and $70 \%$. 
Table 2. Selected consultant studies (no peer-reviewed studies available) analysing the waterbed effect due to $\mathrm{CO}_{2}$ floor price implementation in Germany.

\begin{tabular}{|c|c|c|c|c|c|c|c|c|}
\hline \multirow[t]{2}{*}{ Study } & \multirow[t]{2}{*}{$\begin{array}{l}\text { Modelled } \\
\text { year }\end{array}$} & \multicolumn{2}{|c|}{$\begin{array}{c}\text { Effective carbon price } \\
\left(€ / \mathrm{tCO} \mathrm{C}_{2}\right)\end{array}$} & \multirow[t]{2}{*}{$\begin{array}{l}\text { Emissions in Germany } \\
\left(\mathrm{MtCO}_{2}\right)\end{array}$} & \multicolumn{2}{|c|}{ Coal production in Germany (TWh) } & \multirow[t]{2}{*}{$\begin{array}{c}\text { Waterbed } \\
(\%)\end{array}$} & \multirow{2}{*}{$\begin{array}{c}\text { Germany } \\
\text { electricity net } \\
\text { importer? }\end{array}$} \\
\hline & & Germany & Rest of EU & & Lignite & Hard coal & & \\
\hline \multirow{2}{*}{$\begin{array}{l}\text { (Matthes et al., } \\
\text { 2018) - WWF }\end{array}$} & \multirow[t]{2}{*}{2020} & $15-35$ & 5.6 & $158-254$ & $26-105$ & $27-56$ & $48-70$ & If $\mathrm{CO}_{2}$ price $>15$ \\
\hline & & $\begin{array}{c}15-35 \text { in } \\
\mathrm{CWE}^{\mathrm{a}}\end{array}$ & 5.6 & $193-262$ & $51-105$ & $44-64$ & $24-54$ & If $\mathrm{CO}_{2}$ price $>15$ \\
\hline \multirow{2}{*}{$\begin{array}{l}\text { (Hermann et al., } \\
\text { 2017) - UBA }\end{array}$} & 2025 & 37 & 27 & 230 & 106 & 47 & ND & No \\
\hline & 2030 & 47 & 37 & 180 & 78 & 32 & 56 & No \\
\hline $\begin{array}{l}\text { (Huneke and Perez } \\
\text { Linkenheil, 2016) - } \\
\text { Brainpool }\end{array}$ & 2030 & 50 or 75 & 27.6 & $144-226$ & ND & ND & 60 & Yes \\
\hline \multirow{4}{*}{$\begin{array}{l}\text { (Fernahl et al., } \\
\text { 2017)- BEE }\end{array}$} & 2020 & $25-80$ & 5 & $102-197$ & $38-95$ & $30-58^{b}$ & $57-64$ & Yes \\
\hline & 2025 & $37-80$ & 17 & $114-249$ & $58-110$ & $50-102^{b}$ & $54-67$ & Yes \\
\hline & 2020 & 30 & 20 & 229 & 90 & 65 & ND & No \\
\hline & 2025 & 45 & 30 & 223 & 100 & 80 & ND & No \\
\hline
\end{tabular}

"ND" accounts for "not defined": data not reported in the studies.

${ }^{\text {a }}$ CWE corresponds to FR, BE, NL, LU, AT, DE, DK.

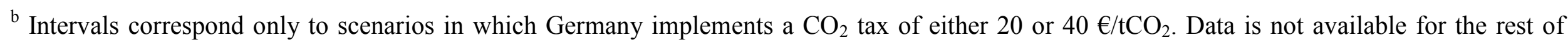
scenarios. 
In addition to the waterbed effect, the studies highlight the reduction of net electricity exports in Germany. In all studies, when the difference between the effective $\mathrm{CO}_{2}$ price in Germany and that of the $\mathrm{EU}$ is higher than $15 € / \mathrm{tCO}_{2}$, Germany becomes a net importer. For instance, a carbon price support of $40 € / \mathrm{tCO}_{2}$ could lead to net imports of roughly $145 \mathrm{TWh} / \mathrm{yr}$ in 2025 (Fernahl et al., 2017). This would break the trend of Germany as a net exporter, which has been the case since 2003. 54 TWh of net exports were witnessed in 2017 (BMWi, 2018).

Other studies only modelled parts of the EU when analysing the impact of different policies aimed at reducing emissions. Some of them focused on the waterbed effect. For instance, assuming different ETS prices and hydro availability, Višković et al. (2017) estimate that carbon leakage would range between 6 and 40\% in the southeast Europe. Brink et al. (2016) compare different supporting policies, which aim to increase the stringency of the EU ETS. Their analysis shows a full temporal waterbed effect by 2030, when all EU ETS members implement a carbon price floor of $20 € / \mathrm{tCO}_{2}$. Other studies focus on the interaction between different policies, particularly renewables support and the EU ETS. For instance, Müsgens (2018) assess that subsidies for RES are required to reach a RES share of $>50 \%$ by 2050 , as the ETS prices alone would not be enough to trigger such investments. Weigt et al. (2013) estimate that carbon emission abatement is higher when a renewable support policy is in place simultaneously with the ETS. Abrell et al. (2017) analyse the interaction between the ETS and non-ETS sectors, when a carbon price floor is implemented in the ETS and there is a fixed overall target. According to their study, a carbon price floor of $50-75 € / \mathrm{tCO}_{2}$ in the ETS leads to the overall lowest costs of climate policy (20-30\% lower than current policy scenario). However, very high carbon price floor prices lead to higher policy costs (e.g., a price of 120 $€ / \mathrm{tCO}_{2}$ would lead to welfare costs up to $10 \%$ higher than the current policy scenario) as further (inefficient) abatement in the ETS is carried out, while cheaper abatement in the nonETS is not exploited. Likewise, Jarke and Perino (2017) determine that a renewable support policy in a capped sector leads to carbon leakage to a non-capped sector within the same economy.

\section{METHODS}

In this section we describe the main characteristics of the LIMES-EU model used in this paper and explain the iterative process used to estimate ETS prices in the presence of a group of countries implementing a carbon price floor. We then present the main data sources and assumptions. We derive an electricity-only cap within the EU ETS as only the electricity 
sector is included in our model. The section concludes with a presentation of the scenarios analysed.

\subsection{Model description}

LIMES-EU is a linear optimisation model that computes electricity dispatch and calculates generation and transmission capacity expansion in five-year steps from 2010 to 2050 for 29 regions in Europe (28 countries and a region aggregating the Balkan countries) at the minimum cost. For each of these years, six representative days are modelled via demand profiles and variable renewable energies (vRES) availability profiles. For each day, eight blocks of three hours are assumed, leading to 48 time slices. These slices are estimated using a cluster algorithm that takes into account the correlation between demand and vRES generation in the different EU countries. This allows $95 \%$ of wind variability to be captured with six representative days (Nahmmacher et al., 2016). LIMES-EU thus captures intra-day demand and supply variability, which allows the short-term variability effects on long-term investment decisions to be analyzed. The model contains 32 storage and generation technologies, including different vintages for lignite, hard coal and gas. The model was calibrated to 2015 data by fixing the generation and transmission capacities to the capacities that existed at that time. The data sources for the main parameters used in the model are described in Appendix $\mathrm{A}^{4}$.

LIMES-EU considers a number of standard constraints, e.g., capacity constraints, resource constraints (e.g., biomass potentials and wind/solar/hydropower availability depending on historical data) and operating constraints (e.g., minimum load and ramping conditions for each technology). LIMES-EU also considers selected EU-wide national climate and energy policies, such as the capacity targets of the National Renewable Energy Action Plans (NREAPS) for 2020 (European Commission, 2013).

Policies can be implemented in LIMES-EU either as quantity restrictions (e.g. coal phase out) or cost changes (e.g. emission tax). The national carbon price support is implemented as an additional cost component in the model. However, finding the appropriate level of support that ensures that the ETS allowance price plus the national carbon price support equals a carbon price floor is challenging because of the waterbed effect. Implementing a carbon price

\footnotetext{
${ }^{4}$ Detailed documentation of LIMES-EU is available at: https://www.pik-potsdam.de/research/sustainable$\underline{\text { solutions/models/limes/limes }}$
} 
reduces the initial ETS price, which in turn implies a higher carbon price and so forth. This is solved using an iterative process that is explained in detail in Appendix B.

\subsection{Background assumptions for all scenarios}

We implemented climate, energy and security of supply policy targets by including constraints on $\mathrm{CO}_{2}$ emissions or on the deployment of certain technologies as follows:

- As LIMES-EU is an electricity sector model, we only cover that portion of the EU ETS and estimate an electricity-only cap decreasing from $892 \mathrm{MtCO}_{2}$ in 2020 to 77 $\mathrm{MtCO}_{2}$ in 2050. This amounts to a cumulated budget of $16 \mathrm{GtCO}_{2}$ (see Appendix $\mathrm{C}$ for a detailed calculation). Given the uncertainty of industry's emissions, we perform a sensitivity analysis of the cap in Appendix D.

- We account for the MSR implicitly by setting the market surplus (bank) to zero in the initial period (year 2020 in the model), which spans 2018 to 2022. We do this based on the assumption that the amount of certificates that will be cancelled by 2023 is of the same order of magnitude as the current market surplus ${ }^{5}$.

- Germany has to achieve its legally binding RES targets (EEG) of $40 \%$ in $2025,55 \%$ in 2035 and $80 \%$ in 2050 (BMWi, 2017). We interpolate these values for the remaining years of our time-horizon. For other countries we do not assume any RES target.

- We do not allow for CCS deployment. Worldwide technological innovation to use captured $\mathrm{CO}_{2}$ for commercial purposes seems unlikely in the medium-term (IEA, 2016). Thus far there are no large-scale power plants with integrated CCS in Europe ${ }^{6}$

- In line with the countries' plans or policies, a progressive nuclear phase-out is completed in Belgium by 2025, in Germany by 2022 and in Switzerland by 2044 .

\footnotetext{
${ }^{5}$ By the end of 2016, the certificate surplus was about 1.7 billion EU allowances (EUA) (EEA, 2017a). According to Perino (2018), in 2019 the MSR is expected to receive 1.45-1.6 billion EUA. By 2023, they estimate that 1.7 billion EUA will be cancelled.

${ }^{6}$ According to the IPCC (2014), achieving mitigation scenarios that reach about 450 ppm $\mathrm{CO}_{2}$-eq in 2100 (consistent with a likely chance to keep warming below $2^{\circ} \mathrm{C}$ ) is unlikely without CCS. Costs would increase up to $138 \%$. However, thus far there is little development of CCS projects, in particular in power generation. There are only two operating projects in the world as of May 2018 (Boundary Dam Carbon Capture and Storage in Canada and Petra Nova Carbon Capture in USA). The only project in Europe, Caledonia Clean Energy, a gas power plant in UK, is at an early development stage and is expected to start operating in the 2020s (Global CCS Institute, 2018). The European Commission (2017) reported that all assessments of carbon capture, transport and storage projects (29 from seven countries) turned out to be economically infeasible. In countries like Germany there is also strong public opposition toward CCS (Jungjohann and Morris, 2014). Recently, five German federal states have prepared decisions or have passed laws limiting or banning underground storage of $\mathrm{CO}_{2}$ (European Commission, 2017).
} 
- Investments in coal-fired plants are only allowed in Poland, Greece and the Balkans, as these countries did not support the sector's public statement of refraining from building coal-fired power plants after 2020 (UNFCCC, 2018).

- Countries implement measures to ensure secure power system operation by having sufficient overcapacity for an emergency. A 10\% capacity margin is assumed, i.e. available capacity (after applying derating factors to the generation technologies and transmission capacity) has to exceed demand by at least $10 \%$ at any time.

\subsection{Scenario setup}

For the reference scenario $(R E F)$, we assumed that the only emission-related policy in place is the EU ETS. In the policy scenario only $D E$ we assumed that only Germany implements a carbon price floor, which increases linearly by $3 € /$ year from $30 € / \mathrm{tCO}_{2}$ in 2020 to $120 € / \mathrm{tCO}_{2}$ in 2050. We initially focused on the impact of Germany being the only country that implements such a measure and run additional scenarios $o n l y D E \_X$ in which we vary the "default" price path by means of multiplying by a factor $X$, with $X$ in the range of $50 \%-150 \%$.

We then analysed the impact of different coalitions of countries implementing the default price path. See Table 3. The 'climate coalition' (ClimaCoalition) includes most of the countries that have pledged to reduce coal in the medium-term (countries that have signed the Past Coal Alliance) and Germany. The members of this coalition were chosen for the sake of the analysis rather than for political reasons. In the scenario allEUETS, we considered that all EU ETS members implement the specific carbon price floor. In two additional scenarios with the same carbon price floors (onlyDE_c and ClimaCoalition_c), we assumed that countries are able to cancel allowances in order to avoid carbon leakage to non-members of the coalition. The certificates to be cancelled were estimated as the difference between the emissions of the respective coalition members in the reference scenario $R E F$ and each of the onlyDE-ClimaCoalition. These certificates were subtracted from the original cap in scenarios onlyDE_c to ClimaCoalition_c. 
Table 3. Scenarios description.

\begin{tabular}{|c|c|c|c|c|}
\hline \multirow[b]{2}{*}{$\begin{array}{l}\text { Certificates } \\
\text { cancellation }\end{array}$} & \multicolumn{4}{|c|}{$\begin{array}{l}\text { Countries implementing a carbon price floor (from } 30 € / \mathrm{tCO}_{2} \text { in } 2020 \text { to } 120 € / \mathrm{tCO} \text { in } \\
\qquad 2050)\end{array}$} \\
\hline & -- & DE & $\begin{array}{l}\text { Nordic, GB, IE, DE, Benelux, AT, CH, } \\
\text { FR, IT, PT }\end{array}$ & $\begin{array}{l}\text { All EU ETS } \\
\text { members }\end{array}$ \\
\hline Not allowed & $R E F$ & onlyDE & ClimaCoalition & allEUETS \\
\hline Allowed & -- & onlyDE_c & ClimaCoalition_c & -- \\
\hline
\end{tabular}

*Benelux: Netherlands, Belgium and Luxemburg.

**Nordic: Sweden, Norway, Denmark and Finland.

For European countries not belonging to the EU ETS (Switzerland and the Balkans), we assumed exogenous $\mathrm{CO}_{2}$ prices. We assumed that Switzerland implements a carbon tax equal to the ETS carbon price in the scenarios $R E F$ and $o n l y D E$, and the default carbon price floor path for scenarios ClimaCoalition and allEUETS. The Balkans apply a $\mathrm{CO}_{2}$ price increasing linearly from $5 € / \mathrm{tCO}_{2}$ in 2020 to $23 € / \mathrm{tCO}_{2}$ in 2050 . We also assume that the UK remains within the EU ETS and keeps a carbon price floor of $20 € / \mathrm{tCO}_{2}$ in 2020 in all scenarios. We performed a sensitivity analysis on parameters with a high level of uncertainty, e.g. the ETS electricity-only cap, fossil fuel prices, vRES capital costs, cross-border transmission expansion and the possibility that a coalition implements a different carbon price floor than Germany.

\section{RESULTS}

European electricity markets were modelled under different assumptions regarding the implementation of a carbon price floor. In this section, we first present the results of our analyses on the impact of different levels of a carbon price floor implemented only by Germany and perform a sensitivity analysis to determine the required price to reach the target in 2030 under different assumptions. We then present the impact of different coalitions of countries implementing a carbon price floor focusing on emissions and coal generation in Germany and in the EU ETS. The section concludes with the simulation of the MSR to estimate the volume of certificates that would need to be cancelled in order to avoid the waterbed effect.

\subsection{Impact of different carbon price floors in Germany}


This section examines the effect in Germany of different carbon price floor paths on the achievement of its 2030 targets. The price paths are a fraction (50-150\%) of the default price (from $30 € / \mathrm{tCO}_{2}$ in 2020 to $120 € / \mathrm{tCO}_{2}$ in 2050), e.g., the scenario onlyDE_50 refers to a price path of $15 € / \mathrm{tCO}_{2}$ in 2020 to $60 € / \mathrm{tCO}_{2}$ in 2050 . In Figure 1 we present a selection of price paths, focusing on the resulting coal generation, emissions and ETS price in 2030. 2015 values are presented to give an idea of the magnitude of emission reductions.

Our results show that German emissions and coal generation decrease considerably even when Germany does not implement a carbon price floor $(R E F)$. Both emissions and coal generation decrease further when a carbon price floor $\left(o n l y D E \_X\right)$ is implemented with respect to the EU ETS-only scenario $(R E F)$. In 2030, coal generation decreases by between 25 $\mathrm{TWh} / \mathrm{yr}($ onlyDE_50) and $113 \mathrm{TWh} / \mathrm{yr}$ (onlyDE_150). Accordingly, emissions decrease by between $26 \mathrm{MtCO}_{2}\left(\right.$ onlyDE_50) and $120 \mathrm{MtCO}_{2}$ (onlyDE_150) with respect to REF. The higher the effective $\mathrm{CO}_{2}$ price (ETS price plus national price support) and the higher the spread between the German effective $\mathrm{CO}_{2}$ price and the ETS price, the larger are the differences in emissions and coal generation between $R E F$ and onlyDE_X. This is because the higher $\mathrm{CO}_{2}$ price in Germany makes German electricity generation from coal less competitive.

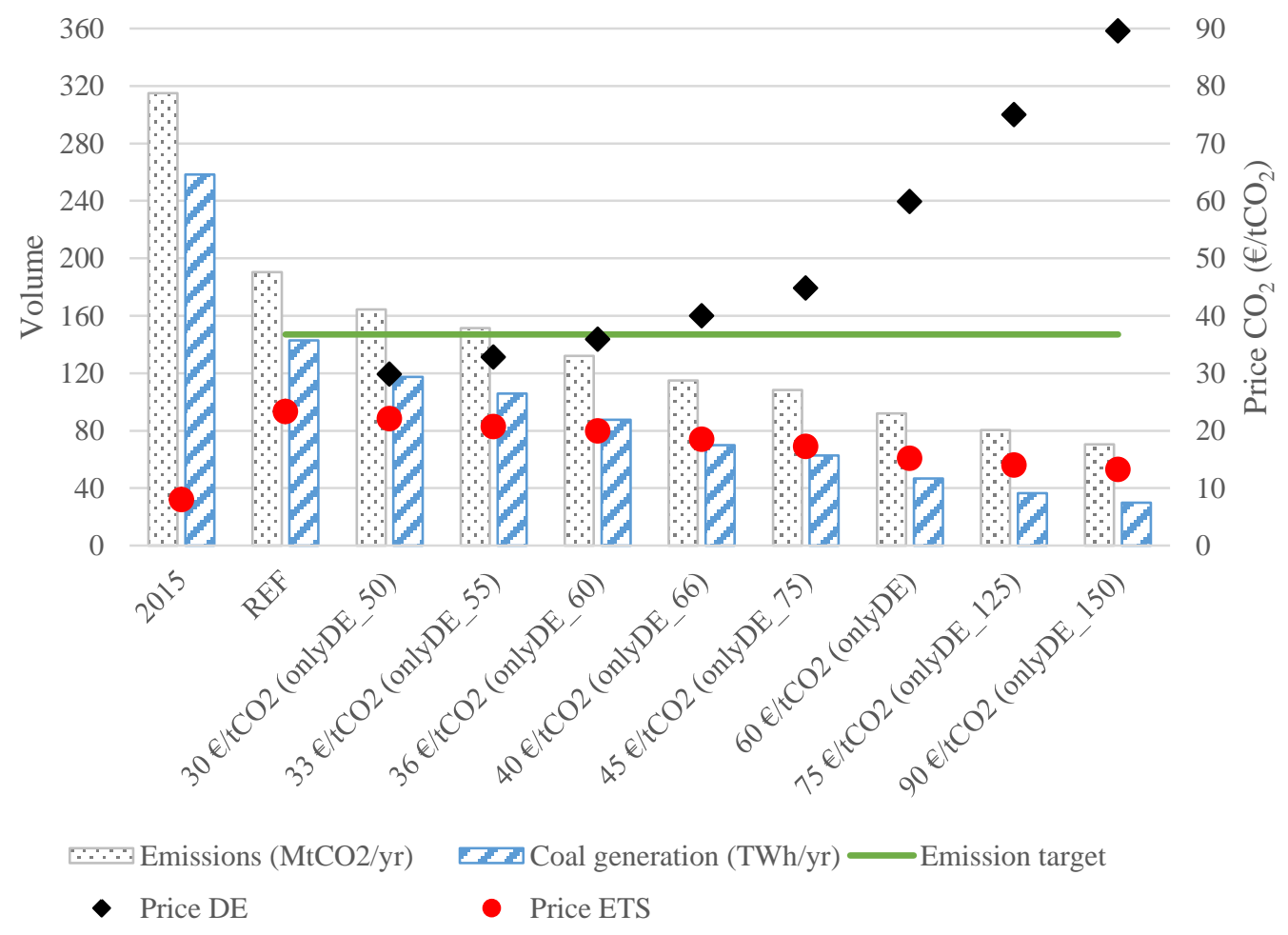

Figure 1. Emissions from electricity generation and coal generation as compared with the effective $\mathrm{CO}_{2}$ price in Germany and the ETS price in 2015 and under different carbon price floor scenarios in 2030. 
The ETS alone would be insufficient to decrease German emissions down to the national target level for 2030. If Germany does not implement any further emission policy $(R E F)$, the ETS price is $23 € / \mathrm{tCO}_{2}$. Although this would cut emissions to $191 \mathrm{MtCO}_{2}$ (almost $50 \%$ lower than in 1990), it would not be enough to reach the emission targets for electricity generation (roughly $\left.147 \mathrm{MtCO}_{2}\right)^{7}$. Germany needs to implement a carbon price floor slightly higher than $33 € / \mathrm{tCO}_{2}$ to reach the targets under our default assumptions.

Although a $\mathrm{CO}_{2}$ price of a magnitude around $33 € / \mathrm{tCO}_{2}$ encourages investments in renewables ${ }^{8}$, the higher RES generation that results does not entirely offset the drop in coalbased generation because of carbon leakage. Renewable generation in 2030 is $25 \mathrm{TWh} / \mathrm{yr}$ higher in onlyDE_55 than in REF (all from wind turbines). Coal and gas generation are 37 $\mathrm{TWh} / \mathrm{yr}$ and $9 \mathrm{TWh} / \mathrm{yr}$ lower, respectively. German generation overall decreases by 22 $\mathrm{TWh} / \mathrm{yr}$ and thus net imports increase from $33 \mathrm{TWh} / \mathrm{yr}(R E F)$ to $55 \mathrm{TWh} / \mathrm{yr}$ (onlyDE_55). (In all carbon price floor scenarios Germany becomes a net importer in 2020, as it does after 2025 in $R E F$ ). While German coal generation is $37 \mathrm{TWh} / \mathrm{yr}$ lower, total coal generation in the EU ETS decreases only by $16 \mathrm{TWh} / \mathrm{yr}$. This means that coal generation in other Member states increases by $21 \mathrm{TWh} / \mathrm{yr}$ because of the lower ETS prices in onlyDE_55 (21€/tCO $\left.\mathrm{th}_{2}\right)$ than in REF (23€/ $\left.\mathrm{tCO}_{2}\right)$. Hence, implementing a carbon price support increases net imports, favouring coal generation in other countries (waterbed effect "in space"). A wider coalition of countries implementing a carbon price floor might help reduce coal generation abroad. This is evaluated in the following section.

\subsection{Achieving the target under different assumptions}

In this section we assess the risk related to achieving the German climate target for electricity generation in $2030\left(147 \mathrm{MtCO}_{2}\right)$. We perform a sensitivity analysis to determine how much the German carbon price required to reach this target would change under different assumptions about uncertain policy and economic parameters.

\footnotetext{
${ }^{7}$ The Climate action plan (BMUB, 2016) sets the emissions target for the energy conversion sector at 175-183 $\mathrm{MtCO}_{2}$-eq (equivalent to 61-62\% reduction) with respect to 1990 (466 $\mathrm{MtCO}_{2}$-eq), as well as a weaker target of $49-51 \%$ reductions for the industry sector, which also encompasses power generation in industry power plants. Based on this, we derive a target for electricity-related power generation emissions. The mentioned target depends on the attribution of emissions for CHP plants and the emission reductions in the rest of the energy supply sector. All emissions attributable to electricity generation (after deducting heat-related emissions from CHP plants) were $366.9 \mathrm{MtCO}_{2}$ in 1990 (Harthan and Hermann, 2018). Industry electricity generation emissions were $33.9 \mathrm{MtCO}_{2}$ in 1990 (Harthan and Hermann, 2018); assuming a 50\% reduction target results in $17 \mathrm{MtCO}_{2}$ in 2030. Deducting the $33.9 \mathrm{MtCO}_{2}$ of industrial emissions gives $333 \mathrm{MtCO}_{2}$ for "energy conversion" electricity emissions. Assuming a reduction of $61 \%$, these emissions should be cut to $130 \mathrm{MtCO}_{2}$. Therefore, the carbon emissions only for power (w/o heat portion of CHP) should add up to $147 \mathrm{MtCO}_{2}$.

${ }^{8}$ The RES target constraint representing the EEG 2017 targets is not binding in any of these scenarios in 2030.
} 
Five main variables are tested whose uncertainty could have major impacts on the EU ETS, and thus on German emissions: the level of the electricity-only cap, fossil fuel prices, vRES capital costs, expansion of cross-border transmission and the coalition's carbon price floor. The remaining assumptions are the same as for onlyDE (only Germany implements a carbon price floor). Combining these variables, we evaluated 12 possible outcomes and estimated the range of the effective carbon price required in Germany such that it may reach its 2030 target. The main assumptions are as follows:

- Electricity-only cap: the impact of easier/more difficult industry decarbonisation. As described in Appendix C, to calculate an electricity-only ETS cap, assumptions are needed regarding the future share of the industry and heating sectors. In two variation scenarios, the 2050 share of ETS certificates required by industry decreases from the default value of $55 \%$ of the total to $45 \%$ (easier industry decarbonisation) or increases to $65 \%$ (more difficult industry decarbonisation). This varies the default budget by 1.6 $\mathrm{GtCO}_{2}(10 \%)$ : the resulting budgets are $17.6 \mathrm{GtCO}_{2}$ and $14.4 \mathrm{GtCO}_{2}$, respectively.

- Fuel prices: price ranges were used from the Sustainable development and Current policies scenarios of the WEO (IEA, 2017) (see Table D1). Oil, gas and hard coal prices in 2025 and 2040 were inter/extrapolated for the full time horizon.

- vRES capital costs: these vary $\pm 20 \%$ after 2025 .

- Cross-border transmission expansion: an extreme scenario was tested in which transmission is kept at 2015 levels through the entire modelling horizon.

- Coalition's carbon price floor: we assumed that Germany implements a carbon price floor high enough to achieve its 2030 target, while the rest of the ClimaCoalition members implement a carbon price floor using the "default" price path (a linear increase from $30 € / \mathrm{t} \mathrm{CO} 2$ in 2020 to $120 € / \mathrm{t} \mathrm{CO} 2$ in 2050).

The two remaining scenarios evaluated (see Table 4) correspond to the "worst" and the "best" case scenarios. These result from the simultaneous combination of all sensitivity variations that increase/decrease the $\mathrm{CO}_{2}$ price required to achieve the 2030 target. In the "all bad" scenario, we assume high gas prices, low coal prices, a low emission budget, expensive vRES, constant transmission and the coalition from ClimaCoalition implementing a default price path. In contrast, in the "all good scenario" we assume low gas prices, high coal prices, a high emission budget, cheap vRES, transmission expansion as in onlyDE and only Germany implementing a carbon price floor. A more general analysis of how these variables affect the 
ETS price as well as coal and gas generation at both German and EU ETS levels (in REF) is provided in Appendix B.

Table 4 shows the effective prices in Germany required to reach the emission targets in 2030. This varies between 24 and $57 € / \mathrm{tCO}_{2}$ : carbon price support varies between 8 and $29 € / \mathrm{tCO}_{2}$. The required price seems to be particularly sensitive to changes in the vRES costs and in transmission expansion. If the scenarios that combine different assumptions are disregarded, the highest price required ( $44 € / \mathrm{tCO}_{2}$ ) is obtained without transmission expansion because fossil-based generation as well as RES with higher availability (e.g., solar energy from southern countries) is locked-in. Consequently, imports are limited and the countries with more polluting generation mixes (including Germany) need to invest more in national RES capacity, whose availability is more limited. This highlights the importance of encouraging a stronger European integration for more efficiently decarbonizing electricity generation.

Table 4. Sensitivity analysis for the effective price and the carbon price support needed in Germany to meet the 2030 emission targets.

\begin{tabular}{|l|c|c|c|}
\hline Scenario & $\begin{array}{c}\text { Required effective price } \\
\text { Germany }\left(\boldsymbol{\epsilon} / \mathbf{t} \mathbf{C O}_{2}\right)\end{array}$ & $\begin{array}{c}\text { ETS price } \\
\left(\boldsymbol{\epsilon} / \mathbf{C O}_{2}\right)\end{array}$ & $\begin{array}{c}\text { Carbon price } \\
\text { support }\left(\boldsymbol{\epsilon} / \mathbf{t} \mathbf{C O}_{2}\right)\end{array}$ \\
\hline High budget $\left(17.6 \mathrm{GtCO}_{2}\right)$ & 32 & 15 & 17 \\
\hline Low budget $\left(14.4 \mathrm{GtCO}_{2}\right)$ & 35 & 27 & 8 \\
\hline Low fossil prices & 35 & 26 & 9 \\
\hline High fossil prices & 35 & 16 & 19 \\
\hline Low gas prices/high coal prices & 32 & 17 & 15 \\
\hline High gas prices /low coal prices & 38 & 21 & 16 \\
\hline Cheap vRES & 25 & 12 & 13 \\
\hline Expensive vRES & 41 & 27 & 14 \\
\hline ClimaCoalition with default price & 39 & 10 & 29 \\
\hline Constant transmission & 44 & 26 & 17 \\
\hline All bad & 57 & 30 & 27 \\
\hline All good & 24 & 7 & 17 \\
\hline
\end{tabular}

4.3.What if Germany is not alone?

We analysed the effect of two differently sized coalitions (see section 3.3) implementing a carbon price floor on emissions and coal generation in Germany and in the EU. When a coalition of countries implements a carbon price floor, ETS prices decrease substantially. See Figure 2. In allEUETS, as all EU ETS members implement the carbon price floor, the emission banking constraint is non-binding (i.e., the ETS price equals zero). They therefore apply a carbon price support equivalent to the carbon price floor. When there is only the ETS $(R E F)$, the ETS price increases from $14 € / \mathrm{tCO}_{2}$ in 2020 to $63 € / \mathrm{tCO}_{2}$ in 2050 . When a coalition of countries implements a carbon price floor, the demand for certificates from these 
countries decreases because fossil-based generation is reduced. This results in lower ETS prices, e.g., $35 \%$ and $75 \%$ lower in onlyDE and ClimaCoalition than in REF, respectively.

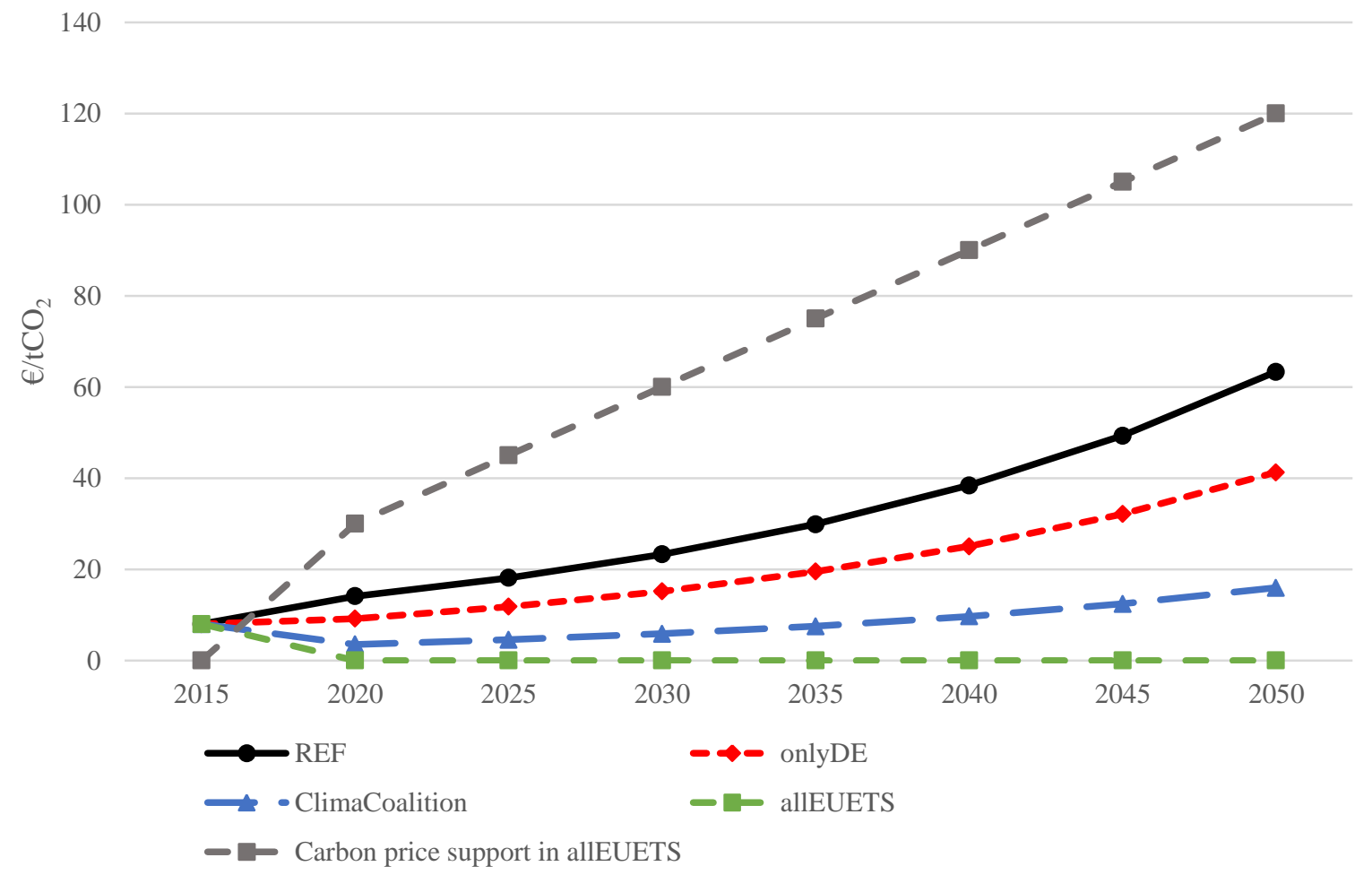

Figure 2. Evolution of ETS prices as different coalitions of countries implement a carbon price floor.

Figure 3(a) shows that higher effective carbon prices in neighbouring countries (as in ClimaCoalition and allEUETS) reduce the decreasing effect of the carbon price floor on coal generation in Germany in 2020 compared to onlyDE. Beyond 2020, the higher neighbouring prices have little influence on German coal use. However, German coal-based generation still remains considerably lower than in $R E F$, at a level of 108 to $144 \mathrm{TWh} / \mathrm{yr}$ in 2020 (REF: 192 $\mathrm{TWh} / \mathrm{yr}$ ) and a level of around $50 \mathrm{TWh} / \mathrm{yr}$ in 2030 (REF: $143 \mathrm{TWh} / \mathrm{yr}$ ). The higher levels of German coal generation in ClimaCoalition and allEUETS compared to onlyDE is due to higher marginal coal costs in other members of the coalition, which allows German coalbased generation to remain competitive. Still, as in onlyDE, Germany becomes a net importer in ClimaCoalition and allEUETS from 2020 onward: while there is a neutral exchange balance by 2020 in REF, net imports lie between 37 and $86 \mathrm{TWh} / \mathrm{yr}$ in allEUETS and onlyDE, respectively. Figure 3(b) shows that emissions are slightly below $100 \mathrm{MtCO}_{2}$ in 2030 in all coalition scenarios, i.e., the emission targets are achieved. 


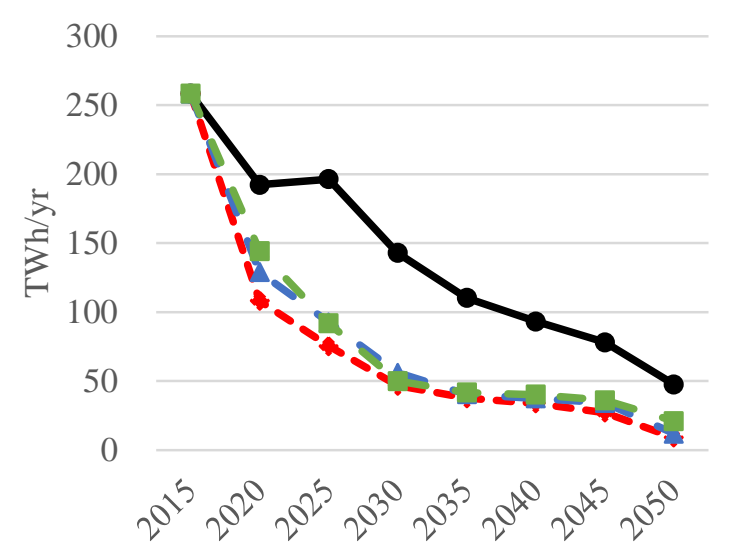

(a)

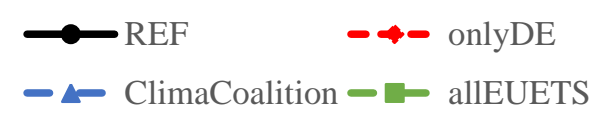

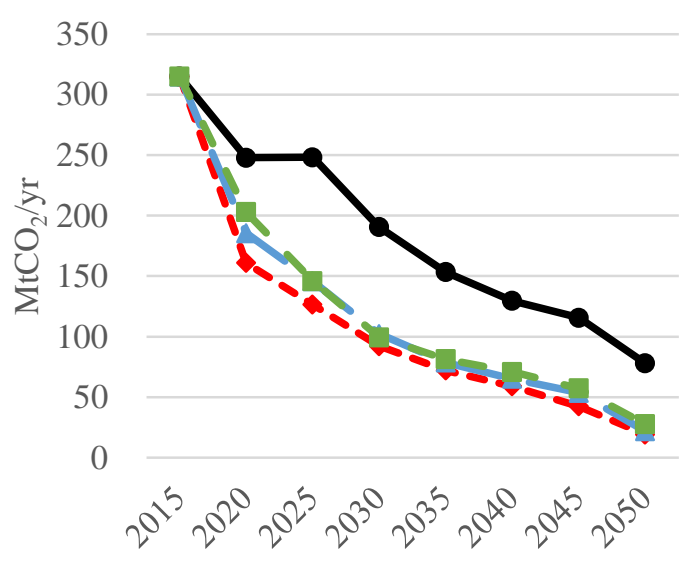

(b)

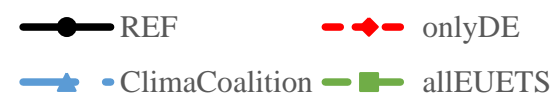

Figure 3. Evolution of (a: left panel) coal-based generation and (b: right panel) emissions from electricity generation in Germany in different policy scenarios.

Given that carbon prices in surrounding countries have some influence on the use of coal in Germany, we made additional runs to investigate which carbon price floor would be required for Germany to meet its 2030 targets. We assumed that the coalition or the entire EU ETS would also implement this price, thereby differing from only $D E$, in which other countries only see the ETS price. The prices are only slightly higher than for only $D E\left(33 € / \mathrm{tCO}_{2}\right): 35 € / \mathrm{tCO}_{2}$ for ClimaCoalition and $37 € / \mathrm{tCO}_{2}$ for allEUETS. When the carbon price floor is implemented by the coalition, the resulting carbon price support equals $19 € / \mathrm{tCO}_{2}$.

\subsection{Estimating the waterbed effect}

When the 'default' path ( $30 € / \mathrm{tCO}_{2}$ in 2020 to $120 € / \mathrm{tCO}_{2}$ in 2050) is applied by Germany or the coalition, the resulting (lower) ETS prices encourage fossil-based generation in countries not belonging to the coalition (waterbed effect in space) and lead to an increase of total EU ETS emissions in the long-term (waterbed effect in time). Figure 4 shows that emissions in EU ETS countries in onlyDE and ClimaCoalition are lower than in REF in the medium-term (until 2030). Hence, emission reductions in Germany and other coalition countries due to additional $\mathrm{CO}_{2}$ prices above $30 € / \mathrm{tCO}_{2}$ also have an EU-wide effect. However, in the longterm the effect reverses, leading to higher total emissions by 2035 in onlyDE and in

\section{ClimaCoalition.}




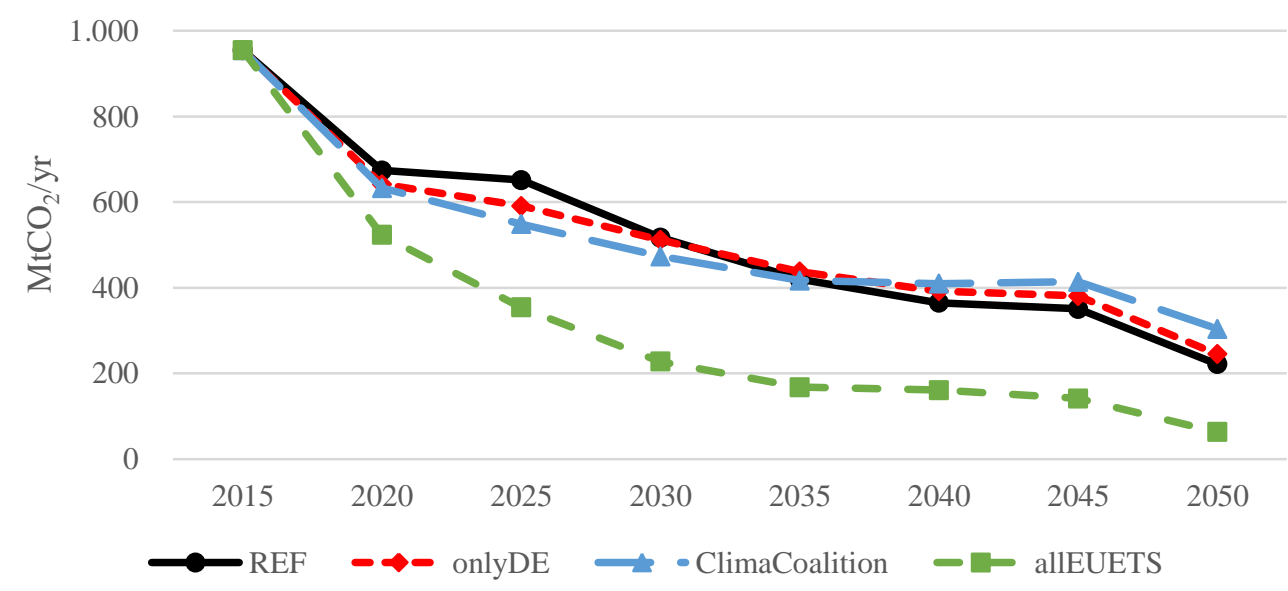

Figure 4. Evolution of emissions from electricity generation in the EU ETS under different policy scenarios.

To illustrate this carbon leakage, we compare coal generation in coalition and non- coalition countries in $R E F$ and ClimaCoalition. See Figure 5. In $R E F$, no one implements a carbon price floor, whereas coalition members do so in ClimaCoalition. If coal-based generation in coalition members (solid lines) in REF (black) is compared with ClimaCoalition (blue), there is a substantial decrease of $\sim 150 \mathrm{TWh} / \mathrm{yr}$ in 2025 . This reduction is partially offset by an increase in coal-based generation in the other countries (dashed lines) from $R E F$ (black) to ClimaCoalition (blue), representing the waterbed effect in space. The total EU-wide change is shown in red bars. Until 2030, the net change is negative - EU-wide coal-based generation is reduced by $\mathrm{CO}_{2}$ carbon price support in the coalition. After 2030, the red bars turn positive coal-based generation increases across the EU through the implementation of a carbon price floor in the coalition. This demonstrates the waterbed effect in "time", which results from the static nature of the 2020-2050 emission cap implemented in the model. 


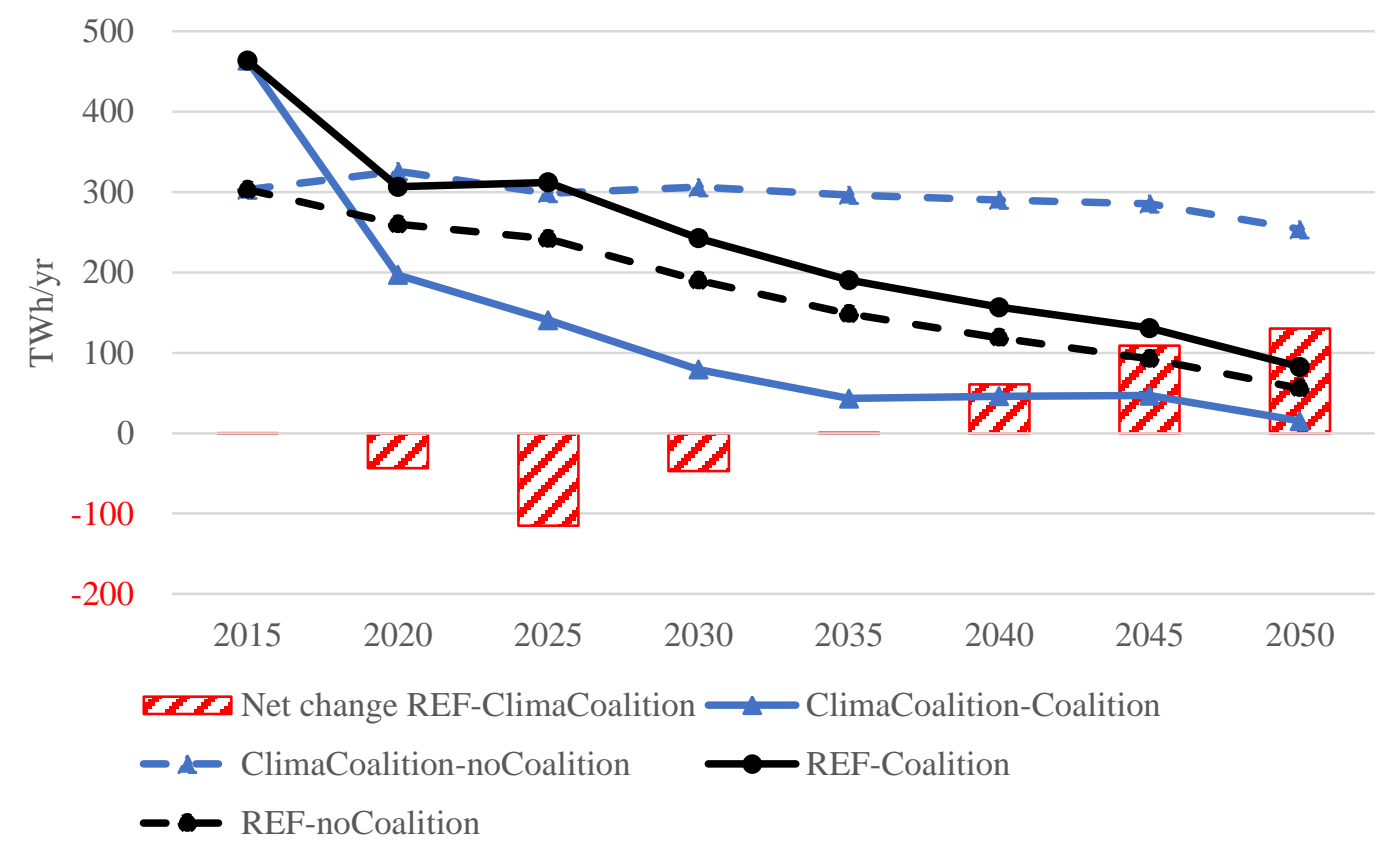

Figure 5. Comparison of coal-based generation in coalition and non-coalition countries in REF and ClimaCoalition.

If the ETS emission cap remains unchanged until 2050, the emission reductions in the medium-term caused by the implementation of a carbon price floor in a sub-group of countries would be completely offset in the long-term without the MSR. Figure 6 shows the cumulated emissions from 2018 to 2032 and 2052 in the EU ETS under different coalitions without the MSR (as each time-step in LIMES-EU accounts for 5 years, 2050 accounts for the period 2048-2052). Emissions until 2032 (blue) are $0.5 \mathrm{GtCO}_{2}, 0.85 \mathrm{GtCO}_{2}$ and $3.7 \mathrm{GtCO}_{2}$ lower in onlyDE, ClimaCoalition and allEUETS respectively than in REF. As Germany reduces its 2018-2032 emissions by $1.4 \mathrm{GtCO} 2$ in onlyDE, a short-term waterbed effect of $\left(1.4 \mathrm{GtCO}_{2}-0.5 \mathrm{GtCO}_{2}\right) / 1.4 \mathrm{GtCO}_{2}=64 \%$ is observed. In ClimaCoalition, the short-term waterbed effect is reduced to $\left(1.7 \mathrm{GtCO}_{2}-0.85 \mathrm{GtCO}_{2}\right) / 1.7 \mathrm{GtCO}_{2}=50 \%$.

However, cumulated emissions until 2052 (black) equal those of $R E F\left(16.0 \mathrm{GtCO}_{2}\right)$ in all scenarios but allEUETS. In the long-term, there is thus a full waterbed effect in onlyDE and ClimaCoalition. Only when all the EU ETS members implement the carbon price floor (allEUETS), there is no waterbed effect and cumulated emissions decrease by $7.8 \mathrm{GtCO}_{2}$ ( 50\%). This reduction of 2020-2050 emissions materializes in allEUETS because the price floor is sufficiently high such that the ETS cap is no longer binding. 


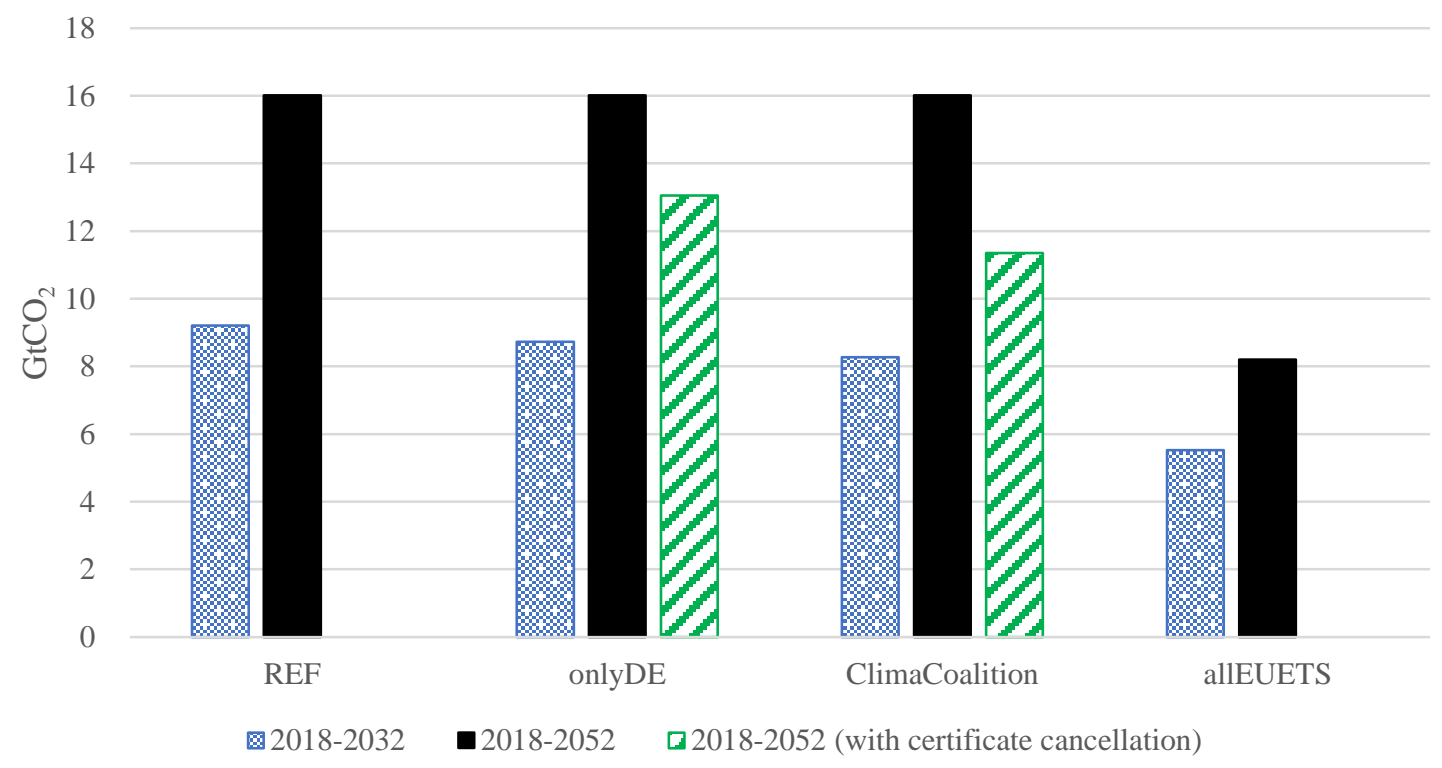

Figure 6. Cumulated emissions from electricity generation in the medium and long-terms (without the MSR). Green bars show long-term emissions with cancellation of certificates (onlyDE_c/ClimaCoalition_c).

A proposed solution to avoid the waterbed effect is to withdraw certificates from the EU ETS. This possibility is now explicitly mentioned in the reformed MSR document ${ }^{9}$, but the exact implementation details are yet to be defined. We quantify the number of certificates that would need to be cancelled to ensure that additional actions by individual states would be completely effective at the EU ETS level. This is equivalent to the difference between emissions of countries implementing a carbon price floor in the reference scenario $(R E F)$ and in the scenarios with a carbon price floor (onlyDE and ClimaCoalition). As more emissions are reduced by a larger coalition, more certificates need to be cancelled: in onlyDE, 3.0 $\mathrm{GtCO}_{2}$ need to be cancelled, while in ClimaCoalition $4.6 \mathrm{GtCO}_{2}$ need to be cancelled. Figure 6 shows the cumulative 2018-2052 emissions from scenarios in which certificates are cancelled in green bars. Cancellation leads to a reduced carbon budget, from $16.0 \mathrm{GtCO}_{2}$ to 13.1 $\mathrm{GtCO}_{2}$ in onlyDE_c and to $11.4 \mathrm{GtCO}_{2}$ in ClimaCoalition_c.

\subsection{Effect of the MSR}

The MSR reform provides for automatic cancellation from 2023 onward. Is this sufficient to prevent the waterbed effect? Using the MSR simulation tool provided by Burtraw et al. $(2018)^{10}$ to assess ex-post cancellation up to 2030 (end of EU ETS Phase IV) shows that this

\footnotetext{
${ }^{9}$ Directive (EU) 2018/410 of the European Parliament and of the Council of 14 March 2018 amending Directive 2003/87/EC to enhance cost-effective emission reductions and low-carbon investments, and Decision (EU) 2015/1814. OJ L 76, 19.3.2018, p. 3-27.

${ }^{10}$ The MSR has three main rules: $(i)$ certificates are withheld from auctioning and sent to the MSR when the bank size of the previous year is higher than $833 \mathrm{MtCO}_{2}$, equalling 24\% (until 2023 and 12\% afterwards) of the
} 
automatic cancellation is only partially successful in preventing the waterbed effect. Additional MSR cancellation in reaction to Germany's increased ambition in onlyDE would amount to $275 \mathrm{MtCO}_{2}$, which only reduces the waterbed effect in 2030 from $64 \%$ to $44 \%$. In the long-term (until 2052), however, the waterbed effect would only be reduced from $100 \%$ to $91 \%$. In this calculation, we assumed that the carbon price floor leads to no additional cancellations through the MSR after 2030 because EU-wide emissions in onlyDE and ClimaCoalition are higher than in $R E F$ at that point in time onward.

We arrive to the waterbed effect estimation by comparing MSR cancellations under the baseline emissions of $R E F$, (equal to $3117 \mathrm{MtCO}_{2}$ - see Table 5, sum of row "baseline cancellation"), with the cancellations in the scenario onlyDE, in which only Germany implements a carbon floor price. While annual emissions in Germany decrease by 1339 $\mathrm{MtCO}_{2}$ between 2018 and 2030 (see Figure 3), the total reduction at the EU ETS-level adds up to only $480 \mathrm{MtCO}_{2}$ in the same period (see Figure 4 and Table 5, row "Additional reductions"). In other words, there is a 64\% waterbed effect until 2030. As the MSR only reacts to EU ETS wide emissions, the total MSR cancellation increases to $3392 \mathrm{MtCO}_{2}$, a difference of $275 \mathrm{MtCO}_{2}$ to the baseline cancellations in $R E F$, thereby reducing the waterbed effect until 2030 to $44 \%$. If Germany wanted to prevent the waterbed effect over the full time horizon (until 2052) and to prevent banking of freed-up certificates for later time periods, it would have to cancel certificates amounting to $1064 \mathrm{MtCO}_{2}\left(=1339-275 \mathrm{MtCO}_{2}\right)$, otherwise the waterbed effect would only be reduced from $100 \%$ to $91 \%{ }^{11}$ in the long-term..

We also simulated the MSR until 2030 for the scenario ClimaCoalition, in which emissions are reduced by $1716 \mathrm{MtCO}_{2}$ between 2018 and 2030, but the total EU-wide reduction adds up only to $850 \mathrm{MtCO}_{2}$ in the same period. In other words, there is a $50 \%$ waterbed effect until 2030. This leads to an MSR cancellation of $3536 \mathrm{MtCO}_{2}: 420 \mathrm{MtCO}_{2}$ are cancelled on top of those in the baseline scenario, reducing the waterbed effect until 2030 from $50 \%$ to $26 \%$. This implies that coalition members would need to voluntarily cancel certificates for $1296 \mathrm{MtCO}_{2}$ $\left(=1716-420 \mathrm{MtCO}_{2}\right)$ to avoid the waterbed effect until 2030. The MSR would only take care of $24 \%$ of the total. In the long term, the additional $420 \mathrm{MtCO}_{2}$ cancelled through the MSR implies a reduction in the full waterbed effect from $100 \%$ to $91 \%(1-420 / 4666)$.

bank size; (ii) certificates are sent back from the MSR to the market when the bank size of the previous year is lower than $400 \mathrm{MtCO}_{2}$; the outtake from the MSR (put in circulation via auctions) equals $100 \mathrm{MtCO}_{2}$; and (iii) when the size of the MSR stock is higher than the number of certificates to be auctioned, the difference between both is cancelled from the MSR. For details of the MSR rules, see (Burtraw et al., 2018).

${ }^{11} 0.91=1-275 / 2955$, where $2955 \mathrm{MtCO}_{2}$ is the amount of certificates that would need to be cancelled to avoid the full waterbed effect in the long-term. 
Table 5. Simulation of MSR when Germany implements a carbon price floor (data in $\mathrm{MtCO}_{2}$ ). Source: Burtraw et al. (2018); own calculations.

\begin{tabular}{|c|c|c|c|c|c|c|c|c|c|c|c|c|c|c|}
\hline & 2018 & 2019 & 2020 & 2021 & 2022 & 2023 & 2024 & 2025 & 2026 & 2027 & 2028 & 2029 & 2030 & SUM \\
\hline \multicolumn{15}{|c|}{ Summarized results from Burtraw et al. (2018) } \\
\hline Emissions & 1,754 & 1,684 & 1,639 & 1,656 & 1,627 & 1,565 & 1,590 & 1,501 & 1,501 & 1,464 & 1,414 & 1,370 & 1,269 & \\
\hline Bank & 1,733 & 1,389 & 1,241 & 1,026 & 1,086 & 956 & 991 & 984 & 912 & 858 & 834 & 830 & 992 & - \\
\hline Intake into MSR & 0 & 416 & 333 & 298 & 246 & 261 & 115 & 119 & 118 & 109 & 103 & 100 & 0 & - \\
\hline Extra intake & & 250 & 1,300 & & & & & & & & & & & \\
\hline Cancellation & 0 & 0 & 0 & 0 & 0 & 2,144 & 303 & 0 & 147 & 145 & 128 & 124 & 125 & 3,117 \\
\hline MSR level & 0 & 666 & 2,299 & 2,597 & 2,843 & 960 & 772 & 891 & 861 & 826 & 801 & 776 & 652 & - \\
\hline \multicolumn{15}{|c|}{ Simulation based on LIMES-EU results - scenario in which Germany implements a carbon floor price (onlyDE) } \\
\hline $\begin{array}{l}\text { Additional reductions } \\
\text { a }\end{array}$ & 32 & 32 & 32 & 32 & 32 & 60 & 60 & 60 & 60 & 60 & 5 & 5 & 5 & 480 \\
\hline Resulting emissions & 1,722 & 1,652 & 1,607 & 1,623 & 1,595 & 1,504 & 1,530 & 1,441 & 1,440 & 1,404 & 1,409 & 1,365 & 1,264 & \\
\hline Bank & 1,765 & 1,446 & 1,316 & 1,116 & 1,186 & 1,093 & 1,172 & 1,203 & 1,165 & 1,142 & 1,089 & 1,060 & 1,100 & \\
\hline Intake into MSR & 0 & 424 & 347 & 316 & 268 & 285 & 131 & 141 & 144 & 140 & 137 & 131 & 127 & \\
\hline Extra intake & & 250 & 1,300 & & & & & & & & & & & \\
\hline Cancellation & 0 & 0 & 0 & 0 & 0 & 2,227 & 329 & 5 & 178 & 176 & 163 & 162 & 152 & 3,392 \\
\hline MSR level & 0 & 674 & 2,321 & 2,637 & 2,904 & 962 & 764 & 899 & 866 & 830 & 804 & 773 & 748 & \\
\hline \multicolumn{15}{|c|}{ Simulation based on LIMES-EU results - scenario in which the 'Climate Coalition' implements a carbon floor price (ClimaCoalition) } \\
\hline $\begin{array}{l}\text { Additional reductions } \\
\mathrm{b}\end{array}$ & 41 & 41 & 41 & 41 & 41 & 103 & 103 & 103 & 103 & 103 & 44 & 44 & 44 & 850 \\
\hline Resulting emissions & 1,713 & 1,643 & 1,598 & 1,615 & 1,586 & 1,462 & 1,488 & 1,399 & 1,398 & 1,362 & 1,370 & 1,326 & 1,226 & \\
\hline Bank & 1,774 & 1,461 & 1,337 & 1,140 & 1,214 & 1,155 & 1,269 & 1,331 & 1,320 & 1,320 & 1,285 & 1,271 & 1,324 & \\
\hline Intake into MSR & 0 & 426 & 351 & 321 & 274 & 291 & 139 & 152 & 160 & 158 & 158 & 154 & 152 & \\
\hline Extra intake & & 250 & 1,300 & & & & & & & & & & & \\
\hline Cancellation & 0 & 0 & 0 & 0 & 0 & 2,249 & 337 & 14 & 194 & 195 & 185 & 186 & 178 & 3,536 \\
\hline MSR level & 0 & 676 & 2,326 & 2,647 & 2,921 & 963 & 765 & 904 & 870 & 833 & 807 & 775 & 750 & \\
\hline
\end{tabular}

${ }^{\text {a }}$ Corresponding to the difference between EU ETS emissions in REF and onlyDE.

${ }^{\mathrm{b}}$ Corresponding to the difference between EU ETS emissions in REF and ClimaCoalition. 


\subsection{Limitations and further work}

Our results show how different groups of countries implementing a carbon price floor influence market dynamics. Although we study the impact of different coalitions, we acknowledge that coalitions might change over a period of 30 years. Coalition formation is a dynamic process in which members join based on market and political reasons. One might expect, for instance, that a carbon price floor is initially implemented by the largest economies and that political pressure (and hopefully the right incentives) will lead other countries to join. This is one of the limitations of our framework. Alternative approaches are needed to analyse the interplay between countries and to determine the conditions under which other countries might join.

Another limitation of our work is related to the evolution of the emission cap. Our results are sensitive to the assumption on the share of emissions accounted for by industry within the EU ETS, highlighting that dynamics in electricity generation can vary depending on the extent of decarbonisation of energy-intensive industry. In further research, we intend to capture more explicitly the interaction between industry and the heating and electricity sectors and its impact on the decarbonisation process. The interaction with non-ETS sectors (e.g., transport) should also be analysed in detail, as the electrification of these sectors will lead to increased electricity demand thereby increasing pressure in the EU ETS.

Finally, further research is needed to endogenize the MSR in a capacity expansion and dispatch model.

\section{CONCLUSION \& DISCUSSION}

Germany set up the "coal commission" to propose measures that would enable the country to phase out coal, and in turn to reach its 2030 climate target. One of the measures considered is a carbon price floor for electricity generation that would reduce additional emissions to the EU ETS, thus filling the "price gap" to reach the target. We analysed two key aspects and related risks for implementing such a carbon price floor: the price level necessary to reach the German 2030 climate target, and the size of the waterbed effect that would arise from such a national carbon price support under the EU-wide emission cap.

Our results show that an effective $\mathrm{CO}_{2}$ price of around $33 € / \mathrm{tCO}_{2}$ would be needed to reach the 2030 targets under default assumptions. For this, a national carbon price support of around 
$12 € / \mathrm{tCO}_{2}$ would be required. However, it would be risky for Germany to set a price support at exactly this level as the appropriate level varies, depending on a number of factors. First, if other countries implement a similar carbon price floor, the competitiveness of German coalfired plants would be favoured, causing their production to increase and requiring a higher carbon price. The evolution of key power sector parameters also impacts the appropriate price level, particularly the expansion of cross-border transmission that could limit imports of relatively cheap renewable electricity. Accordingly, to ensure that the 2030 level will be reached with certainty, even under unfavourable conditions, a carbon price floor of around 57 $€ / \mathrm{tCO}_{2}$ would be required. If, however, conditions turn out to be favourable, a price of only 24 $€ / \mathrm{tCO}_{2}$ would be needed and the target would be overachieved. To avoid both over- and undershoot, the level could be set to adapt over time and in response to how market conditions unfold.

We also investigate policy interaction and related risks with the EU ETS caused by the waterbed effect "in space" and "in time" when Germany or a coalition of countries takes additional action. With a view on cumulated emissions until 2030, we find that the implementation of a stringent carbon price floor would reduce German emissions by around $1339 \mathrm{MtCO}_{2}$ until 2030, while emissions in neighbouring countries would go up by 860 $\mathrm{MtCO}_{2}$, implying a $64 \%$ waterbed effect without MSR. An ex-post estimate shows that the MSR would cancel about $275 \mathrm{MtCO}_{2}$, reducing the waterbed effect until 2030 to $44 \%$. If more countries were to implement such a carbon floor price, the waterbed effect until 2030 would be reduced from $64 \%$ to $50 \%$ without MSR. More certificates would be cancelled through the MSR (420 $\mathrm{MtCO}_{2}$ ), further reducing the waterbed effect until 2030 to $26 \%$. As a result, less unilateral cancellation would be needed. A coalition of countries can therefore reduce emissions, at least in the medium-term.

In the long-term (until 2050), if the ETS cap for the trading periods between 2030 and 2050 is not tightened, these reductions are almost completely offset. The waterbed effect would occur to almost a full extent even when the coalition is large (91\%), underlining that the long-term effect of automatic MSR cancellations is limited. Of course, whether or not the full waterbed effect actually materializes crucially depends on future reforms that may further tighten the caps for the trading periods 2030-2040 and 2040-2050 in response to additional national actions. At the same time, it must be noted that the cancellation provision of the 2018 ETS reform is subject to review in 2021, and might eventually become ineffective. This underlines the considerable regulatory uncertainty around the interaction of national policies with the EU 
ETS, and makes a strong case for implementing price floors and sequencing national action to the EU level.

Is it then advisable for Germany to implement such a carbon price floor? Strengthening the ETS and pursuing an EU-wide approach would clearly be the preferred choice. Under the current political situation in many member states, this might take years or even decades - too long to ensure that the 2030 target is reached. A carbon price floor has the advantage of being easily implemented - by a country or group of countries - and of aligning with the EU ETS, at least when allowances are cancelled such that its integrity is not undermined. Cancelling allowances is thus instrumental for sending a strong message that the EU ETS will continue to play an important role and that European climate policy will not renationalize, and could pave the way for a carbon price floor at the EU-level.

\section{APPENDIX}

A. Model data sources

We used data from publicly available sources to calibrate and run our model. Demand was taken from the EU reference scenario (European Commission, 2016a) for EU members and from SFOE (2013) for Switzerland. Final demand for Norway and the Balkans was estimated by scaling demand in 2010 according to their neighbouring countries' demand growth rates. Initial capacities were set exogenously. The existing capacities of generation and storage technologies as well as their age structure was derived from Platts (2011), EUROSTAT (2013) and the Open Power System Data (2018); in specific cases, data from national ministries, e.g., BMWi (2018) was used. Capacity data in 2020 used as fixed (for conventional sources) or as lower bounds (for vRES) was taken from ENTSO-E (2017a). Cross-border transmission capacities for 2010 was taken from ENTSO-E (2010) and for 2015 from ACER/CEER (2017). For 2025 and 2030, cross-border transmission capacities (used as benchmark in the model) was taken from the TYNDP 2016 (ENTSO-E, 2015).

Capital costs and fuel costs was taken from the REMIND model ${ }^{12}$. Using generation data from ENTSO-E (2017b), we estimated nuclear availability factors per country in 2015 for calibration purposes, but for the remaining years a constant availability factor was assumed for all the countries. Except for hydro and vRES, the annual availability of generation technologies is equal for all model regions. Hydropower availability factors were estimated

\footnotetext{
${ }^{12}$ For REMIND, detailed harmonized model documentation is available at the Common IAM documentation, https://www.iamcdocumentation.eu/Model__Documentation\_-_REMIND.
} 
from IRENA (2017) data and were assumed to remain constant for the entire simulation. For vRES, data from (IRENA, 2017) was also used to estimate annual availability factors for existing facilities. Newly installed capacity has higher availability factors, for this data was used from NREL (2013) for wind and Pietzcker et al. (2014) for PV. This accounts for the improvements in efficiencies and the trend toward lower turbine-to-rotor ratios for wind. Technologies "waste" and "other gases" were only considered for Germany. Their availability and emission factors were calculated based on 2015 generation (BMWi, 2016). We considered transmission losses equal to $8 \%$ and a rate of autoconsumption for each technology from Agora (2014) to better account for gross demand in the long-term in scenarios with high share of vRES.

As mentioned in Section 3.1, in order to capture hourly and seasonal variations, we used a cluster algorithm to estimate representative times slices of demand and vRES availability. We used ENTSO-E (2016) data for the historic electricity demand levels and historic weather data from ECMWF (2018) for the vRES infeed. Table A1 summarizes the main parameters used for each technology. 
Table A1. Main parameters used to model the operation of technologies in LIMES-EU.

\begin{tabular}{|c|c|c|c|c|c|c|c|c|c|c|}
\hline Technology & $\begin{array}{l}\text { Lifetime } \\
(\mathrm{yr})\end{array}$ & $\begin{array}{l}\text { Build } \\
\text { time } \\
(\mathrm{yr})\end{array}$ & $\begin{array}{l}\text { Investment } \\
\text { costs } \\
(2010 € / k \mathbf{k})^{\mathrm{e}}\end{array}$ & Efficiency $^{\mathrm{f}}$ & $\begin{array}{l}\text { Hourly } \\
\text { availability }\end{array}$ & $\begin{array}{l}\text { Annual } \\
\text { availability }\end{array}$ & $\begin{array}{l}\text { Fixed O\&M } \\
\text { costs (factor } \\
\text { of inv. Costs } \\
\text { per yr) }\end{array}$ & $\begin{array}{l}\text { Variable } \\
\text { costs } \\
\text { (€/MWh) }\end{array}$ & $\begin{array}{l}\text { Emission } \\
\text { factor } \\
\text { (GtC/ZJth) }\end{array}$ & $\begin{array}{l}\text { Auto- } \\
\text { consumption }\end{array}$ \\
\hline Nuclear & 60 & 3.1 & 7000 & 0.33 & 1 & 0.9 & 0.03 & 5 & 0.0 & 0.05 \\
\hline Hard coal & 45 & 2.2 & 1800 & $0.38-0.5$ & 1 & 0.8 & 0.02 & 6 & 26.3 & 0.08 \\
\hline Hard coal with CCS & 45 & 2.2 & $3475->2600$ & 0.43 & 1 & 0.8 & 0.02 & 29 & 2.6 & 0.08 \\
\hline Lignite coal & 55 & 2.2 & 2100 & $0.36-0.47$ & 1 & 0.8 & 0.02 & 9 & 29.2 & 0.08 \\
\hline Lignite with CCS & 55 & 2.2 & $3475->2044$ & 0.42 & 1 & 0.8 & 0.02 & 34.3 & 2.9 & 0.08 \\
\hline $\begin{array}{l}\text { Natural gas combined } \\
\text { cycle }\end{array}$ & 45 & 1.3 & 900 & $0.54-0.6$ & 1 & 0.8 & 0.03 & 4 & 15.2 & 0.03 \\
\hline $\begin{array}{l}\text { Natural gas combined } \\
\text { cycle with CCS }\end{array}$ & 45 & 1.3 & $1942->1450$ & 0.52 & 1 & 0.8 & 0.03 & 18 & 1.5 & 0.03 \\
\hline Natural gas turbine & 45 & 0.5 & 400 & 0.41 & 1 & 0.8 & 0.03 & 3 & 15.2 & 0.03 \\
\hline Hydropower & 80 & 1.8 & 2500 & 1 & $\mathrm{a}$ & $\mathrm{c}$ & 0.02 & 0 & 0.0 & 0.02 \\
\hline Biomass & 45 & 1.3 & 2000 & 0.42 & 1 & 0.8 & 0.04 & 6 & 0.0 & 0.05 \\
\hline Wind onshore & 25 & 0.8 & $1291->1150$ & 1 & $\mathrm{~b}$ & $\mathrm{c}$ & 0.03 & 0 & 0.0 & 0 \\
\hline Wind offshore & 25 & 1.2 & $4073->2829$ & 1 & $\mathrm{~b}$ & $\mathrm{c}$ & 0.05 & 0 & 0.0 & 0 \\
\hline PV & 25 & 0.5 & $950->500$ & 1 & $\mathrm{~b}$ & $\mathrm{c}$ & 0.01 & 0 & 0.0 & 0 \\
\hline Concentrated solar & 30 & 1.0 & $4760->3560$ & 1 & $\mathrm{~b}$ & $\mathrm{c}$ & 0.03 & 0 & 0.0 & 0 \\
\hline Pumped-storage & 80 & 1.8 & 1500 & 0.8 & d & $d$ & 0.01 & 0 & 0.0 & 0 \\
\hline Hydrogen electrolysis & 20 & 0.5 & $1620->820$ & 0.7 & d & d & 0.02 & 3 & 0.0 & 0 \\
\hline Oil & 40 & 1.3 & 400 & 0.42 & 1 & 0.8 & 0.04 & 3 & 22.0 & 0.09 \\
\hline Hydrogen combined & 40 & 1.3 & 1170 & 0.58 & 1 & 0.8 & 0.03 & 4 & 0.0 & 0.03 \\
\hline
\end{tabular}




\begin{tabular}{|c|c|c|c|c|c|c|c|c|c|c|}
\hline cycle & & & & & & & & & & \\
\hline $\begin{array}{l}\text { Hydrogen combustion } \\
\text { turbine }\end{array}$ & 40 & 0.5 & 520 & 0.33 & 1 & 0.8 & 0.04 & 3 & 0.0 & 0.03 \\
\hline Hydrogen fuel cell & 40 & 0.5 & $1600->700$ & 0.45 & 1 & 0.8 & 0.02 & 3 & 0.0 & 0.03 \\
\hline Waste incineration & 40 & 1.3 & 2000 & 0.22 & 1 & 0.8 & 0.04 & 3 & 42.0 & 0.2 \\
\hline $\begin{array}{l}\text { Other fossil-based } \\
\text { plants, e.g., coke gas }\end{array}$ & 40 & 1.3 & 900 & 0.76 & 1 & 0.8 & 0.03 & 3 & 55.3 & 0.08 \\
\hline Li-ion batteries & 20 & 1.8 & $1343->735$ & 0.8 & d & d & 0.01 & 0 & 0.0 & 0 \\
\hline
\end{tabular}

${ }^{\mathrm{a}}$ Country-dependent availability (based on 2010-2015 generation and capacities)

${ }^{\mathrm{b}}$ Country and hourly-dependent availability

${ }^{\mathrm{c}}$ Dependent on hourly availabilities

${ }^{\mathrm{d}}$ Dependent on energy input (endogenous variable)

${ }^{\mathrm{e}}$ For those technologies with two values, the first corresponds to the investment costs in 2020 and the second to those in 2050

${ }^{\mathrm{f}}$ For those technologies with two values, they correspond to the range of efficiencies depending on the time the plant was built 
B. Iterative approach to estimating a national/regional carbon price floor in a LP model

Fell et al. (2012) formulated a model to provide insight into different ways to implement a carbon price, e.g., price floors and ceilings. Firms maximise their profits (resulting revenues from buying and selling emission certificated) subject to a certificates trading constraint in a cap-and-trade system, i.e., they are allowed to bank and borrow certificates. The Fell et al. (2012) formulation allows one to ensure a carbon price floor for a group of countries sharing the same cap-and-trade constraint (in this case, the EU ETS). The authors show, through the first order condition for optimality, that the selling price equals the Lagrange multiplier on the banking/borrowing constraint. To increase the allowance price, the firm buys back certificates from the market. This nonetheless affects the market price, which is the same for all firms. Adapting this formulation as such to LIMES-EU would not allow us to analyse different countries implementing a carbon price floor. It only allows analysis of all EU ETS members implementing such a policy.

To cope with this limitation, we implemented an iterative process (see Figure B1). In a first iteration $(i=1)$ the model was run without exogenous carbon price support $\left(x_{t, c, i}\right)$. If the $\mathrm{CO}_{2}$ price (Lagrange multiplier of the state equation of the allowances bank) $\left(P_{t, i}\right)$ is lower than the desired carbon price floor $\left(P_{t, c}^{*}\right)$ for every country $c$ and time $t$, the model needed to be run again. In the next run, we assumed an exogenous $\mathrm{CO}_{2}$ price, i.e., the needed carbon price support, equivalent to the difference between the desired carbon price floor $\left(P_{t, c}^{*}\right)$ and $P_{t, i}$ (see Figure B2). From the results of this new iteration, we estimated $P_{t, i+1}$. If the "new" total $\mathrm{CO}_{2}$ price (carbon price support plus the Lagrange multiplier of the state equation of the allowances bank, i.e., $\left.x_{t, c, i}+P_{t, i+1}\right)$ is not within the tolerance interval $\left(P_{t, c}^{*} \pm t o l\right)$, a new iteration was needed by estimating $x_{t, c, i+1}$. This was done iteratively until a solution was found. The parameter tol is set to $1 \%$. 


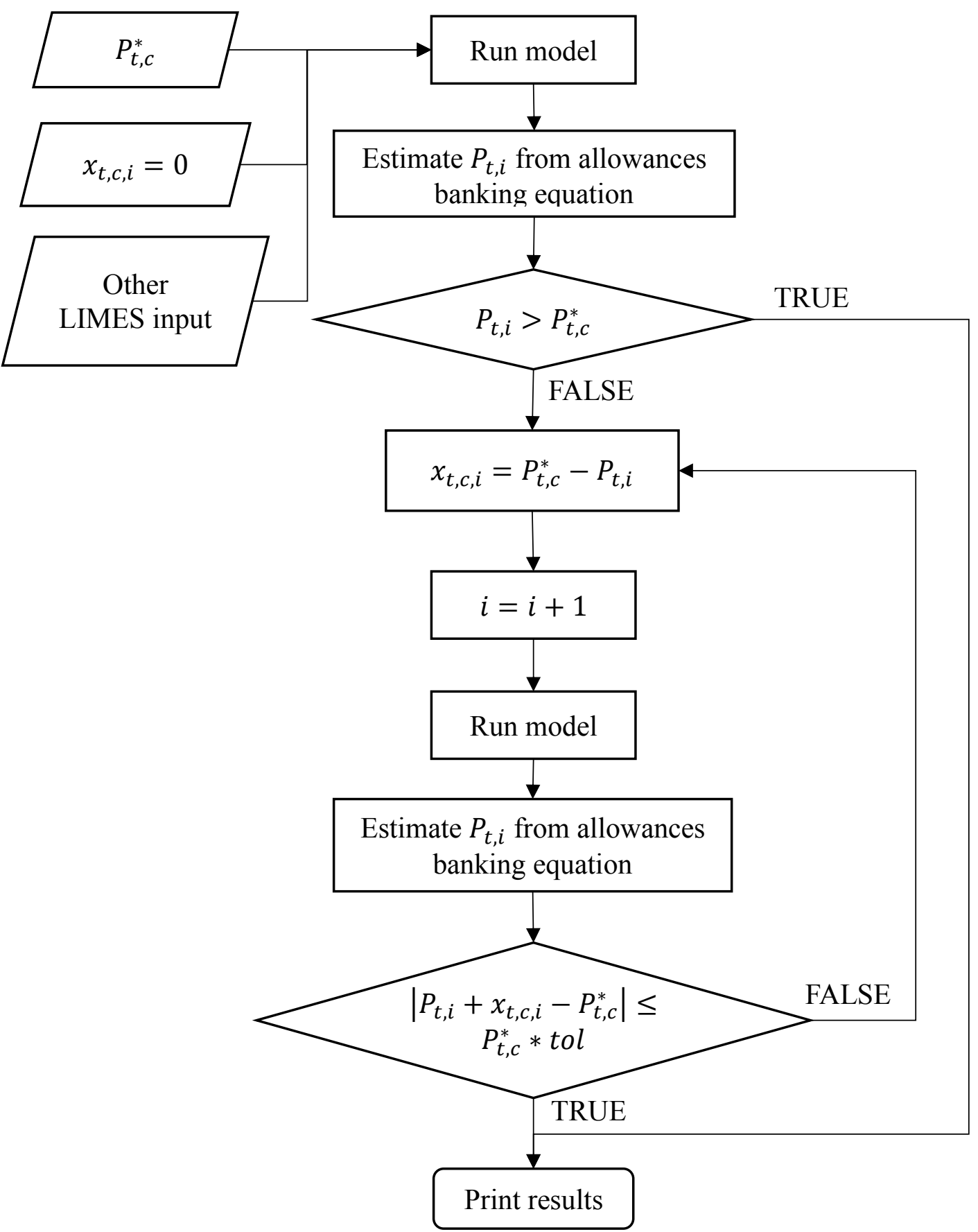

Figure B1. Flow diagram explaining the iterative process used to run the model when a carbon price floor was implemented. 


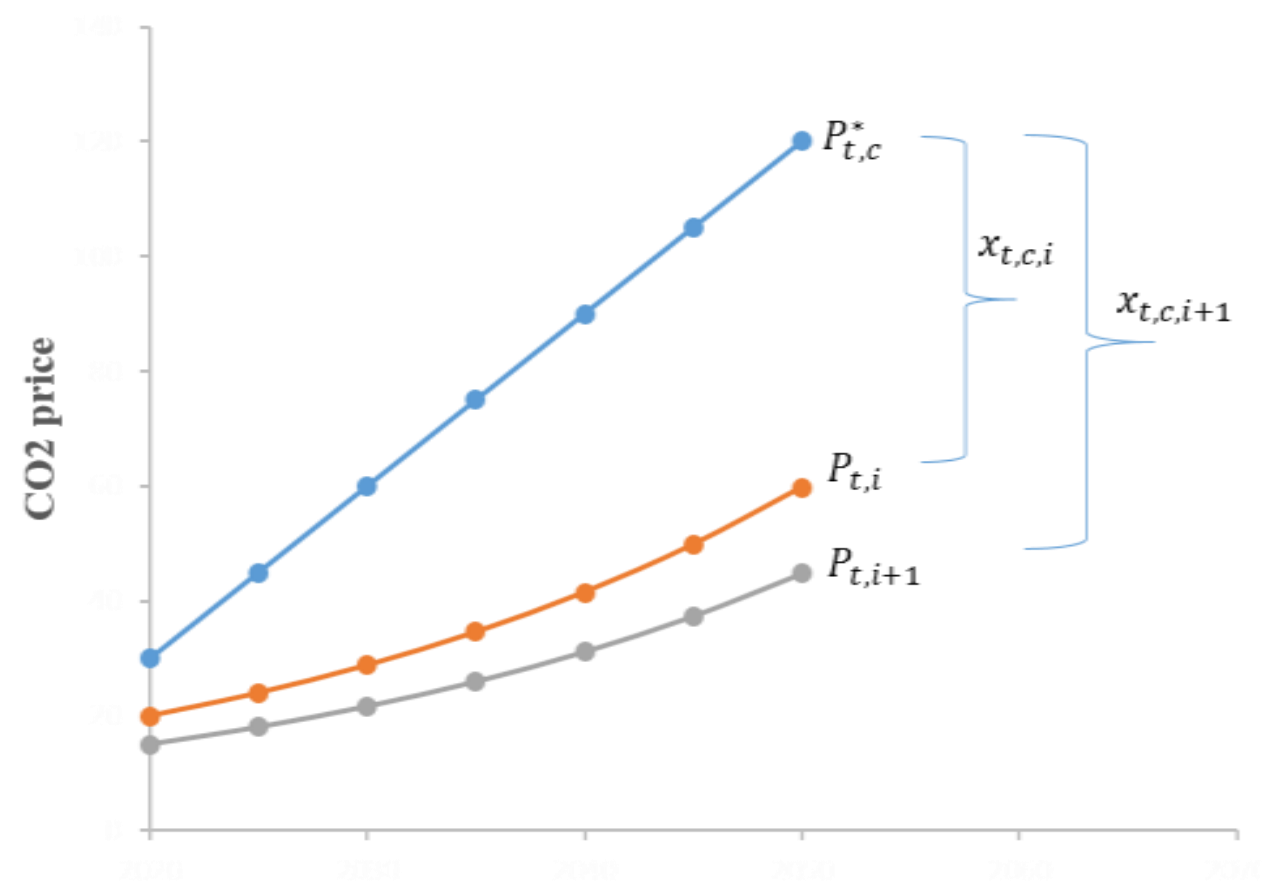

Time

Figure B2. Carbon price support adjustment between two iterations, for countries implementing a carbon price floor.

C. Estimation of an electricity-only cap within the EU ETS

The current EU ETS comprises two main sectors: aviation and the stationary sector (energy industries). The latter comprises electricity and heating production, and industry (e.g., petroleum refining). Aviation was included in the ETS ${ }^{13}$ in 2012, but the extent of its coverage changed between 2012 and 2016. This sector has its own cap (set at $210 \mathrm{MtCO}_{2}$ for each year between 2013-2020 ${ }^{14}$ ), but in the event of a shortage, airlines are allowed to buy allowances from the stationary sector (EEA, 2016). The cap for the stationary sector was set at 2084 $\mathrm{MtCO}_{2}$ in 2013, after which it decreases at a rate of $1.74 \%$ per year until 2020. For the period 2021-2030 ( $4^{\text {th }}$ trading phase of the EU ETS), the cap decreases at a rate of $2.2 \%$ per year in order to achieve a $43 \%$ reduction of emissions with respect to 2005 (EEA, 2016). Although a decreasing rate beyond 2030 is not yet set, emissions are expected to drop $80-95 \%$ by 2050 with respect to 2005 (European Commission, 2016b); we assumed a reduction of 90\%. For

\footnotetext{
${ }^{13}$ Directive 2008/101/EC of the European Parliament and of the Council of 19 November 2008 amending Directive 2003/87/EC so as to include aviation activities in the scheme for greenhouse gas emission allowance trading within the Community. O.J. L 8, 13.1.2009, p. 3-21.

14 Decision of the EEA joint committee No 93/2011 of 20 July 2011 . Available at https://ec.europa.eu/clima/sites/clima/files/ets/allowances/aviation/docs/eea_20072011_en.pdf
} 
the calculation of an electricity-only cap, we used only the stationary sector cap despite the allowance for the aviation sector to buy allowances from this sector. We assumed that the aviation cap would be set after 2020 according to the decarbonisation possibilities in this sector.

The challenge of estimating an electricity-only cap lies in assessing the emission path of the heating and industry sectors. As Figure $\mathrm{C} 1$ shows, emissions from the combustion of fuels decreased from $1461 \mathrm{MtCO}_{2}$ in 2005 to $1181 \mathrm{MtCO}_{2}$ in 2015 (EEA, 2018). Using the energy balances from Eurostat (2017) and the emission factors from the IPCC's guidelines (Gomez et al., 2006) for the period 2005-2015, we estimated electricity- and heating-related emissions: $940 \mathrm{MtCO}_{2}$ and $223 \mathrm{MtCO}_{2}$ in 2015, respectively. Emissions from other industries accounted for $639 \mathrm{MtCO}_{2}$. To reflect current ETS scope, industries' share in the total verified emissions remained around 35\% during the same period. Given the difficulty of decarbonising such industries, we assumed that the share of these industries would increase linearly to $55 \%$ in 2050. We also assumed that the share of heating remains constant (12\%) until 2050. The resulting electricity-only cap was thus estimated to decrease from $896 \mathrm{MtCO}_{2}$ in 2020 to 76 $\mathrm{MtCO}_{2}$ in 2050.

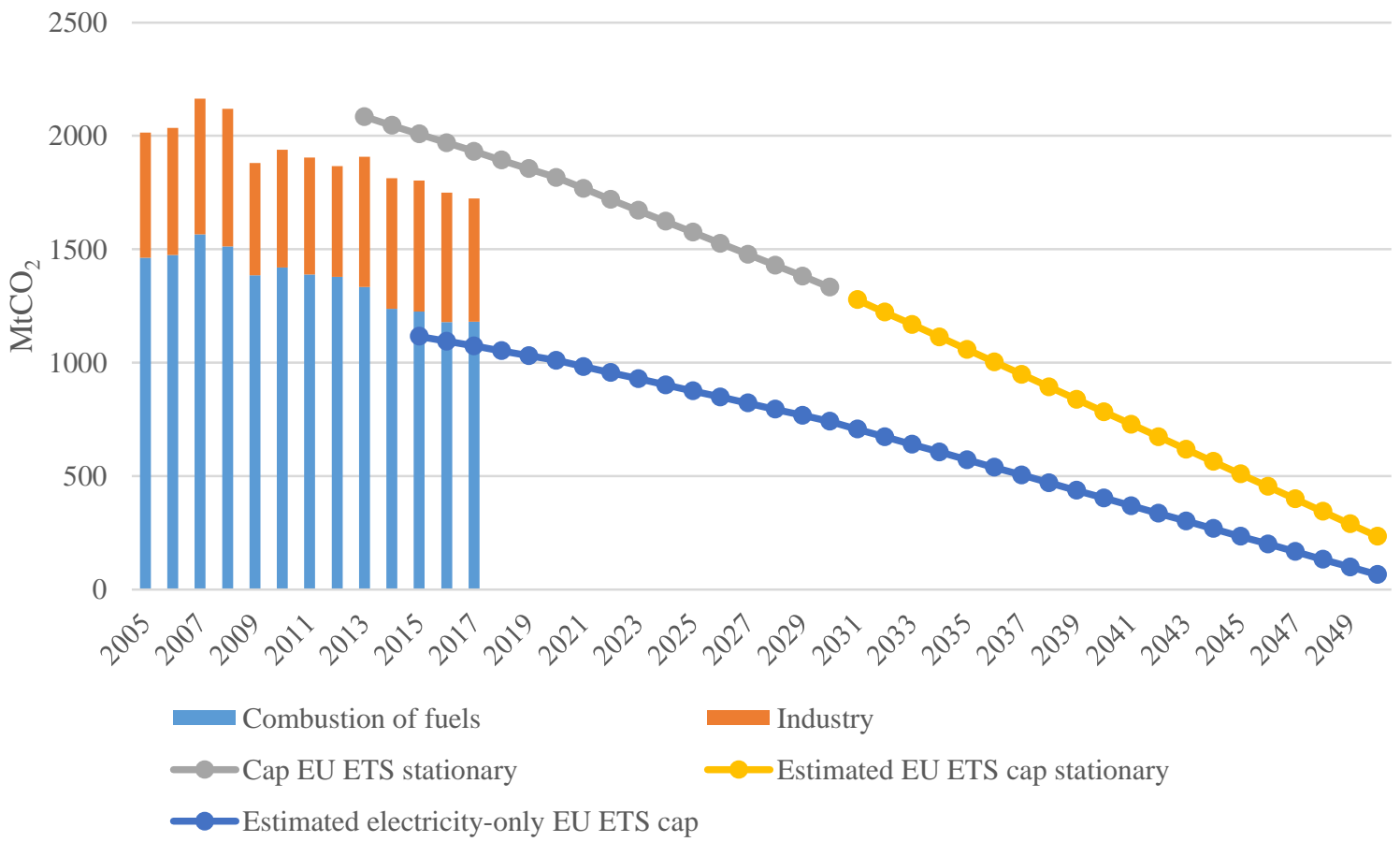

Figure C1. Evolution of historical emissions and estimation of the future overall EU ETS cap and electricity-only cap within the EU ETS. Data sources: (EEA, 2017b, 2016), own calculations. 


\section{Complementary sensitivity analysis}

The following analysis was performed based on $R E F$ assumptions: there is only an emissions cap-and-trade system and there is no country implementing a carbon price floor.

We evaluated the sensitivity to the cap by varying the share of the certificates used by industry by $\pm 10 \%$. The resulting budgets are $17.6 \mathrm{GtCO}_{2}$ and $14.4 \mathrm{GtCO}_{2}$. ETS prices are $24 \%$ lower (higher) when the cap is higher (lower).

To evaluate the impact of high and low fuel prices, we used price ranges from the Sustainable development and Current policies scenarios of the WEO (IEA, 2017) (see Table D1). Oil, gas and hard coal prices were provided for 2025 and 2040, which we inter/extrapolated for the full time horizon. Since the high coal prices provided by the WEO are slightly lower than our $R E F$ scenario, and given recent market dynamics (coal prices are currently around $70-100 \$ / \mathrm{t}$ (2.8-4 \$/GJ) (MarketWatch, 2018), so WEO prices seem to be low), we assumed high coal prices were $30 \%$ higher than in our REF scenario. Our results are more sensitive to higher fuel prices than to low prices. With high prices, coal generation is less affected due to the loss of competitiveness of gas-fired plants. With high prices, coal-based generation decreases by $3 \%$ on average, while gas-based generation decreases by $12 \%$ on average in Germany. As a result, net imports increase further to fill this gap (up to $16 \mathrm{TWh} / \mathrm{yr}$ ). With low prices, both German coal and gas generation increase slightly, by an average of $2 \%$ and $3 \%$, respectively. At an EU ETS-level, when fuel prices are low, coal-based generation slightly decreases (on average $<1 \%$ ) and gas-based generation increases (on average 6\%). When fuel prices are high, coalbased generation increases (on average 5\%) and gas-based generation decreases considerably (18\%). Overall, $35 \%$ of the gas-based generation drop is replaced by coal-based generation when fuel prices are high. The rest is provided by RES (mainly wind energy). The highest coal-based generation increase by far occurs in Poland (37\%, equivalent to $23 \mathrm{TWh} / \mathrm{yr}$ ). ETS prices are $23 \%$ lower when fuel prices are high and $20 \%$ higher when fuel prices are low. This implies that a higher (lower) $\mathrm{CO}_{2}$ price is needed to decarbonise the system when fuel prices are low (high). 
Table D1. Fuel prices used for the sensitivity analysis and comparison with REF assumptions (€/GJ). Source: IEA (2017); own calculations.

\begin{tabular}{|l|l|r|r|r|r|r|r|r|r|}
\hline & & 2015 & 2020 & 2025 & 2030 & 2035 & 2040 & 2045 & 2050 \\
\hline \multirow{4}{*}{ Coal } & Low & 2.3 & 2.1 & 2.3 & 2.3 & 2.2 & 2.2 & 2.2 & 2.1 \\
\cline { 2 - 10 } & \multicolumn{1}{|l}{ REF } & 2.3 & 3.0 & 3.0 & 3.0 & 3.1 & 3.2 & 3.4 & 3.6 \\
\cline { 2 - 10 } & High & 2.3 & 2.3 & 2.8 & 2.9 & 3.1 & 3.2 & 3.4 & 3.6 \\
\hline \multirow{4}{*}{ Gas } & Low & 5.3 & 5.8 & 6.6 & 6.9 & 7.2 & 7.5 & 7.8 & 8.1 \\
\cline { 2 - 11 } & REF & 5.3 & 6.2 & 6.8 & 7.1 & 7.8 & 8.3 & 8.4 & 8.9 \\
\cline { 2 - 10 } & High & 5.3 & 6.3 & 7.8 & 8.5 & 9.2 & 9.9 & 10.7 & 11.4 \\
\hline \multirow{3}{*}{ Oil } & Low & 8.0 & 11.0 & 12.3 & 11.8 & 11.4 & 10.9 & 10.5 & 10.0 \\
\cline { 2 - 10 } & REF & 8.0 & 11.9 & 13.2 & 14.3 & 16.4 & 16.0 & 17.6 & 19.3 \\
\cline { 2 - 10 } & High & 8.0 & 13.2 & 16.5 & 18.8 & 21.0 & 23.2 & 25.4 & 27.6 \\
\hline
\end{tabular}

In addition to the scenarios run for Section 4.2, we also tested the impact of a substantial reduction in vRES capital costs (50\% after 2025). At an EU ETS-level, such reduction in vRES capital costs leads to considerable increases in vRES generation (8\% solar and $34 \%$ wind, on average). Still, this is insufficient to entirely displace fossil-based generation. In fact, coal generation increases by $10 \%$, while gas-based generation decreases by $37 \%$. This can be explained by the reduction in $\mathrm{CO}_{2}$ prices from the combination of a fixed EU ETS cap and cheaper vRES: $\mathrm{CO}_{2}$ prices decrease by $90 \%$ compared to $R E F$ (the resulting price grows from $1 € / \mathrm{tCO}_{2}$ in 2020 to $7 € / \mathrm{tCO}_{2}$ in 2050$)$.

\section{ACKNOWLEDGEMENTS}

We thank Christian Flachsland, Oliver Tietjen and Dallas Burtraw for their helpful comments. This work was supported by the German Federal Ministry of Education and Research (BMBF) under the research project ENavi. Robert Pietzcker's contribution was funded by the European Union's Horizon 2020 research and innovation programme under grant agreement No 730403 (INNOPATHS). Michael Pahle's contribution was supported by Stiftung Mercator Foundation under the research project AHEAD. 


\section{REFERENCES}

Abrell, J., Rausch, S., Yonezawa, H., 2017. Higher Price, Lower Costs? Minimum Prices in the EU Emissions Trading Scheme. Scand. J. Econ. https://doi.org/10.1111/sjoe.12279

ACER/CEER, 2017. Annual Report on the Results of Monitoring the Internal Electricity and Gas Markets in 2016. Electricity Wholesale Markets Volume. Agency for the Cooperation of Energy Regulators/Council of European Energy Regulators.

Agora, 2014. Vorschlag für eine Reform der Umlage-Mechanismen im EEG. Agora Energiewende.

Agora Energiewende, 2016. Eleven Principles for a Consensus on Coal: Concept for a stepwise Decarbonisation of the German power sector (Short Version) (No. 092/03-I2016/EN). Berlin.

Agora, IDDRI, 2017. Focus on the electricity sector. Co-dependent impacts of German and French choices on nuclear and coal in the context of renewable energy development.

Begemann, E., Long, L., Neelis, M., 2016. The waterbed effect and the EU ETS. An explanation of a possible phasing out of Dutch coal fired power plants as an example (Report commissioned by ENECO). Ecofys, Utrecht.

BMUB, 2016. Climate action plan 2050. Federal Ministry for the Environment, Nature Conservation, Building and Nuclear Safety (BMUB), Berlin.

BMWi, 2018. Energiedaten: Gesamtausgabe [WWW Document]. BMWi.de. URL http://www.bmwi.de/DE/Themen/Energie/Energiedaten-und-

analysen/Energiedaten/gesamtausgabe,did=476134.html (accessed 3.26.18).

BMWi, 2017. Renewable Energy Sources Act (EEG 2017).

BMWi, 2016. Energiedaten: Gesamtausgabe [WWW Document]. BMWi.de. URL http://www.bmwi.de/DE/Themen/Energie/Energiedaten-undanalysen/Energiedaten/gesamtausgabe,did=476134.html (accessed 7.29.16).

BMWi, BMU, 2010. Energy Concept. Federal Ministry of Economics and Technology (BMWi) and Federal Ministry for the Environment, Nature Conservation and Nuclear Safety (BMU), Berlin.

Brink, C., Vollebergh, H.R.J., van der Werf, E., 2016. Carbon pricing in the EU: Evaluation of different EU ETS reform options. Energy Policy 97, 603-617. https://doi.org/10.1016/j.enpol.2016.07.023 
Burtraw, D., Keyes, A., Zetterberg, L., 2018. Companion Policies under Capped Systems and Implications for Efficiency-The North American Experience and Lessons in the EU Context (RFF report). Resources for the Future.

Carbon Market Watch, 2017. Beyond the EU ETS: Strengthening Europe's carbon market through national action. Carbon Mark. Watch.

Die Bundesregierung, 2018. Koalitionsvertrag zwischen CDU, CSU und SPD (Coalition contract between CDU, CSU and SPD).

EC, 2015. Proposal for a DIRECTIVE OF THE EUROPEAN PARLIAMENT AND OF THE COUNCIL amending Directive 2003/87/EC to enhance cost-effective emission reductions and low-carbon investments.

ECMWF, 2018. ERA-Interim (Jan 1979 - present). Public dataset [WWW Document]. URL http://apps.ecmwf.int/datasets/ (accessed 6.5.18).

Edenhofer, O., Flachsland, C., Wolff, C., Schmid, L.K., Leipprand, A., Koch, N., Kornek, U., Pahle, M., 2017. Decarbonization and EU ETS Reform: Introducing a price floor to drive low-carbon investments (Policy Paper). Mercator Research Institute on Global Commons and Climate Change (MCC), Berlin.

Edenhofer, O., Schmidt, C.M., 2018. Klimaschutz mit Frankreich. Frankf. Allgemaine Ztg. 22.

EEA, 2018. EU Emissions Trading System (ETS) data viewer [WWW Document]. Eur. Environ. Agency. URL https://www.eea.europa.eu/data-andmaps/dashboards/emissions-trading-viewer-1 (accessed 11.2.18).

EEA, 2017a. Trends and projections in the EU ETS in 2017. The EU Emissions Trading System in numbers (No. 18/2017). European Environment Agency, Copenhagen.

EEA, 2017b. Annual European Union greenhouse gas inventory 1990-2015 and inventory report 2017 (Submission to the UNFCCC Secretariat No. 6/2017). European Environment Agency, Copenhagen.

EEA, 2016. Trends and projections in Europe 2016 - Tracking progress towards Europe's climate and energy targets (Publication No. 24/2016). European Environment Agency, Copenhagen.

Enervis Energy Advisors, 2015. Der Klimaschutzbeitrag des Stromsektors bis 2040. Entwicklungspfade für die deutschen Kohlekraftwerke und deren wirtschaftliche Auswirkungen. (Studie im Auftrag von Agora Energiewende No. 081/15-S-2015/DE). Berlin.

ENTSO-E, 2017a. Medium-term adequacy forecast 2017. ENTSO-E, Brussels. 
ENTSO-E, 2017b. Production data [WWW Document]. URL https://www.entsoe.eu/data/data-portal/\#consumption-data (accessed 6.5.17).

ENTSO-E, 2016. Consumption data - Hourly load values [WWW Document]. URL https://www.entsoe.eu/data/data-portal/\#consumption-data (accessed 6.5.18).

ENTSO-E, 2015. Ten-Year Network Development Plan (TYNDP) 2016.

ENTSO-E, 2010. NTC Values Summer 2010. Final version (6 July 2010) [WWW Document]. URL https://docs.entsoe.eu/dataset/ntc-values-2006-2010 (accessed 1.24.13).

European Commission, 2017. REPORT FROM THE COMMISSION TO THE EUROPEAN PARLIAMENT AND THE COUNCIL on Implementation of Directive 2009/31/EC on the Geological Storage of Carbon Dioxide.

European Commission, 2016a. EU Reference Scenario 2016. Energy, transport and GHG emissions. Trends to 2050 (No. ISBN 978-92-79-52374-8). European Commission, Luxembourg.

European Commission, 2016b. Emissions cap and allowances [WWW Document]. Clim. Action - Eur. Comm. URL https://ec.europa.eu/clima/policies/ets/cap_en (accessed 5.29.18).

European Commission, 2013. National action plans [WWW Document]. URL /energy/en/topics/renewable-energy/national-action-plans (accessed 9.12.13).

European Council, 2017a. Reform of the EU emissions trading system - Council endorses deal with European Parliament - Consilium [WWW Document]. URL http://www.consilium.europa.eu/en/press/press-releases/2017/11/22/reform-of-the-euemissions-trading-system-council-endorses-deal-with-european-parliament/ (accessed 3.27.18).

European Council, 2017b. Reform of the EU emissions trading scheme [WWW Document]. URL http://www.consilium.europa.eu/en/policies/climate-change/reform-eu-ets/ (accessed 3.29.18).

European Union, 2015. EU ETS Handbook.

EUROSTAT, 2018. Infrastructure - electricity - annual data (nrg_113a) [WWW Document]. URL http://ec.europa.eu/eurostat/en/web/products-datasets/-/NRG_113A (accessed 1.16.18).

Eurostat, 2017. Energy balance EU28 2015 (June 2017 edition). Luxembourg. 
Fell, H., Burtraw, D., Morgenstern, R.D., Palmer, K.L., 2012. Soft and hard price collars in a cap-and-trade system: A comparative analysis. J. Environ. Econ. Manag. 64, 183-198. https://doi.org/10.1016/j.jeem.2011.11.004

Fernahl, A., Perez Linkenheil, C., Huneke, F., Küchle, I., 2017. Wirkungsweise einer CO2Steuer im Strommarkt (Study on behalf of the German Renewable Energy Federation (BEE)). Energy Brainpool, Berlin.

Fischer, C., Preonas, L., 2010. Combining Policies for Renewable Energy: Is the Whole Less Than the Sum of Its Parts? Int. Rev. Environ. Resour. Econ. 4, 51-92. https://doi.org/10.1561/101.00000030

Global CCS Institute, 2018. Projects Database: Large-scale CCS facilities [WWW Document]. URL http://www.globalccsinstitute.com/projects (accessed 5.22.18).

Gomez, D., Watterson, J.D., Americano, B.B., Ha, C., Marland, G., Matsika, E., Namayanga, L., Osman-Elasha, B., Kalenga Saka, J.D., Treanton, K., Quadrelli, R., 2006. 2006 IPCC Guidelines for National Greenhouse Gas Inventories. Volume 2. Energy. Chapter 2: Stationary combustion. IPCC.

Goulder, L.H., Stavins, R.N., 2011. Challenges from State-Federal Interactions in US Climate Change Policy. Am. Econ. Rev. 101, 253-257. https://doi.org/10.1257/aer.101.3.253

Graichen, P., Matthes, F.C., 2018. Vom Wasserbett zur Badewanne. Die Auswirkungen der EU-Emissionshandelsreform 2018 auf $\mathrm{CO}_{2}$-Preis, Kohleausstieg und den Ausbau der Erneuerbaren (No. 136/03-A-2018/DE). Agora Energiewende and Öko-Institut e.V., Berlin.

Harthan, R.O., Hermann, H., 2018. Sektorale Abgrenzung der deutschen Treibhausgasemissionen mit einem Schwerpunkt auf die verbrennungsbedingten CO2Emissionen. Öko-Institut, Berlin.

Heinrichs, H.U., Markewitz, P., 2017. Long-term impacts of a coal phase-out in Germany as part of a greenhouse gas mitigation strategy. Appl. Energy 192, 234-246. https://doi.org/10.1016/j.apenergy.2017.01.065

Heinrichs, H.U., Schumann, D., Vögele, S., Biß, K.H., Shamon, H., Markewitz, P., Többen, J., Gillessen, B., Gotzens, F., Ernst, A., 2017. Integrated assessment of a phase-out of coal-fired power plants in Germany. Energy 126, 285-305. https://doi.org/10.1016/j.energy.2017.03.017

Hermann, H., Loreck, C., Ritter, D., Greiner, B., Keimeyer, F., Bartelt, N., Bittner, M., Nailis, D., Klinski, S., 2017. Klimaschutz im Stromsektor 2030 - Vergleich von Instrumenten zur Emissionsminderung (Study on behalf of the German Environment Agency 
(UBA)). Öko-Institut, Büro für Energiewirtschaft und technische Planung GmbH and Hochschule für Wirtschaft und Recht Berlin (HWR).

Huneke, F., Perez Linkenheil, C., 2016. The effect of a CO2-price floor on the emissions of the german power plant fleet (White Paper). Energy Brainpool, Berlin.

IEA, 2017. World Energy Outlook 2017. OECD/IEA, Paris, France.

IEA, 2016. Medium-Term Coal Market Report 2016. International Energy Agency, Paris.

IPCC, 2014. Climate Change 2014: Synthesis Report. Contribution of Working Groups I, II and III to the Fifth Assessment Report of the Intergovernmental Panel on Climate Change [Core Writing Team, R.K. Pachauri and L.A. Meyer (eds.)]. (A report of the Intergovernmental Panel on Climate Change). IPCC, Geneva, Switzerland.

IRENA, 2017. Renewable Electricity Capacity and Generation Statistics [WWW Document]. URL http://resourceirena.irena.org/gateway/dashboard/index.html?topic=4\&subTopic=54 (accessed 3.20.18).

Jarke, J., Perino, G., 2017. Do renewable energy policies reduce carbon emissions? On caps and inter-industry leakage. J. Environ. Econ. Manag. 84, 102-124. https://doi.org/10.1016/j.jeem.2017.01.004

Jungjohann, A., Morris, C., 2014. The German Coal Conundrum: The status of coal power in Germany's energy transition. Heinrich Böll Foundation, Washington D.C.

Klaus, S., Beyer, C., Jaworski, P., 2012. Allokationsmethoden der Reststrommengen nach dem Entwurf des Kohleausstiegsgesetzes (Studie im Auftrag der Greenpeace Deutschland e.V.). Ecofys.

Knopf, B., Burghaus, K., Flachsland, C., Jakob, M., Koch, N., Edenhofer, O., 2018. Shifting Paradigms in Carbon Pricing. Intereconomics 53, 135-140.

MarketWatch, 2018. Coal (API2) CIF ARA (ARGUS-McCloskey) Nov 2018 [WWW Document]. MarketWatch. URL http://www.marketwatch.com/investing/future/mtfz8/charts (accessed 11.15.18).

Matthes, F.C., 2017. Decarbonizing Germany's Power Sector: Ending Coal with a Carbon Floor Price? (Notes de l'Ifri). Ifri.

Matthes, F.C., Emele, L., Hermann, H., Loreck, C., Frank, P., Ziegenhagen, I., Cook, V., 2017. Germany's electric future. Coal phase-out 2035 (Report by Öko-Institut e. V. and Prognos on behalf of WWF Germany No. ISBN 978-3-946211-12-9). WWF, Berlin. 
Matthes, F.C., Hermann, H., Loreck, C., Ludig, S., 2018. Dem Ziel verpflichtet. CO2Mindestpreise im Instrumentenmix einer Kohle-Ausstiegstrategie für Deutschland (Study on behalf of WWF Germany). Öko-Institut, Berlin.

Meinshausen, M., Meinshausen, N., Hare, W., Raper, S.C.B., Frieler, K., Knutti, R., Frame, D.J., Allen, M.R., 2009. Greenhouse-gas emission targets for limiting global warming to $2{ }^{\circ} \mathrm{C}$. Nature $458,1158-1162$. https://doi.org/10.1038/nature08017

Müsgens, F., 2018. Equilibrium prices and investment in electricity systems with CO2emission trading and high shares of renewable energies. Energy Econ. https://doi.org/10.1016/j.eneco.2018.07.028

Nahmmacher, P., Schmid, E., Hirth, L., Knopf, B., 2016. Carpe diem: A novel approach to select representative days for long-term power system modeling. Energy 112, 430442. https://doi.org/10.1016/j.energy.2016.06.081

Netherlands Environmental Assessment Agency, 2008. Consequences of the European Policy Package on Climate and Energy. Initial assessment of the consequences for the Netherlands and other Member States.

NREL, 2013. Global CFDDA-based Onshore and Offshore Wind Potential Supply Curves by Country, Class, and Depth (quantities in GW and PWh) - OpenEI DOE Open Data [WWW Document]. URL https://openei.org/doe-opendata/dataset/global-cfdda-basedonshore-and-offshore-wind-potential-supply-curves-by-country-class-and-depth-q (accessed 6.5.18).

Newbery, D.M., 2018. Policies for decarbonizing a liberalized power sector. Economics: the Open-Access, Open-Assessment E-Journal, 12, 2018-40.

Open Power System Data, 2018. National generation capacity [WWW Document]. URL https://data.open-power-system-data.org/national_generation_capacity/2017-07-07/ (accessed 6.5.18).

Pahle, M., 2010. Germany's dash for coal: Exploring drivers and factors. Energy Policy, Large-scale wind power in electricity markets with Regular Papers 38, 3431-3442. https://doi.org/10.1016/j.enpol.2010.02.017

Pahle, M., Burtraw, D., Tietjen, O., Flachsland, C., Edenhofer, O., 2018. Preserving the integrity of the EU ETS under unilateral action.

Perino, G., 2018. New EU ETS Phase 4 rules temporarily puncture waterbed. Nat. Clim. Change 8, 262-264. https://doi.org/10.1038/s41558-018-0120-2 
Pietroni, A., Fernahl, A., Perez Linkenheil, C., Niggemaier, M., Huneke, F., 2017. Klimaschutz durch Kohleausstieg (Studie im Auftrag der Greenpeace e.V.). Energy Brainpool, Berlin.

Pietzcker, R.C., Stetter, D., Manger, S., Luderer, G., 2014. Using the sun to decarbonize the power sector: The economic potential of photovoltaics and concentrating solar power. Appl. Energy 135, 704-720. https://doi.org/10.1016/j.apenergy.2014.08.011

Platts, 2011. UDI World Electric Power Plants Data Base (September 2011). S\&P Global Platts.

Reuters, 2018. France calls on EU nations to adopt carbon price floor. Reuters.

Sandbag, 2017. An agenda for strategic reform of the ETS. What's the future for EU carbon pricing? Sandbag.

SFOE, 2013. Perspectives énergétiques 2050 (Energy perspectives 2050). Swiss Federal Office of Energy.

SRU, 2017. Kohleausstieg jetzt einleiten. German Advisory Council on the Environment, Berlin.

Staffell, I., 2017. Measuring the progress and impacts of decarbonising British electricity. Energy Policy 102, 463-475. https://doi.org/10.1016/j.enpol.2016.12.037

UNFCCC, 2018. European Energy Producers Commit to No New Coal Plants after 2020 | UNFCCC [WWW Document]. URL https://unfccc.int/news/european-energyproducers-commit-to-no-new-coal-plants-after-2020 (accessed 7.12.18).

Van den Bergh, K., Delarue, E., D'haeseleer, W., 2013. Impact of renewables deployment on the $\mathrm{CO} 2$ price and the $\mathrm{CO} 2$ emissions in the European electricity sector. Energy Policy 63, 1021-1031. https://doi.org/10.1016/j.enpol.2013.09.003

Višković, V., Chen, Y., Siddiqui, A.S., 2017. Implications of the EU Emissions Trading System for the South-East Europe Regional Electricity Market. Energy Econ. 65, 251261. https://doi.org/10.1016/j.eneco.2017.04.033

Weigt, H., Ellerman, D., Delarue, E., 2013. CO2 abatement from renewables in the German electricity sector: Does a CO2 price help? Energy Econ., Supplement Issue: Fifth Atlantic Workshop in Energy and Environmental Economics 40, S149-S158. https://doi.org/10.1016/j.eneco.2013.09.013 